\title{
STEMMUS-UEB v1.0.0: Integrated Modelling of Snowpack and Soil Mass and Energy Transfer with Three Levels of Soil Physical Process Complexities
}

\author{
Lianyu $\mathrm{Yu}^{1}$, Yijian Zeng ${ }^{1}$, Zhongbo Su${ }^{1,2}$ \\ ${ }^{\mathbf{1}}$ Faculty of Geo-information Science and Earth Observation (ITC), University of Twente, Enschede, The \\ Netherlands \\ ${ }^{2}$ Key Laboratory of Subsurface Hydrology and Ecological Effect in Arid Region of Ministry of Education, \\ School of Water and Environment, Chang' an University, Xi'an, China \\ Correspondence to: Yijian Zeng (y.zeng@utwente.nl); Zhongbo Su (z.su@utwente.nl)
}

\begin{abstract}
Snowpack, as the indispensable component in cold regions, has a profound effect on the hydrology and surface energy conditions through its modification of the surface albedo, roughness, and insulating property. Although the modelling of the snowpack, soil water dynamics, and the coupling of the snowpack and underlying soil layer has been widely reported, the analysis of coupled liquid-vapor-air flow mechanisms considering the snowpack effect was not yet investigated in detail. In this study, we incorporated the snowpack effect (Utah Energy Balance model, UEB) into a common modeling framework (Simultaneous Transfer of Energy, Mass, and Momentum in Unsaturated Soils with Freeze-Thaw, STEMMUS-FT), with various complexities of mass and energy transfer physics (from the basic coupled, to advanced coupled water and heat transfer, and further to the explicit consideration of airflow, termed BCD, ACD, and ACD-air, respectively). We then utilized the in situ observations and numerical experiments to investigate the effect of snowpack on soil moisture and heat transfer with the above-mentioned model complexities. Results indicated that the abrupt increase of surface albedo after precipitation events can be only reproduced by models considering snowpack. The BCD model tended to overestimate the land surface latent heat flux. Such overestimations were largely reduced by ACD and ACD-air models. Compared with the simulation considering snowpack, there is less surface latent heat flux from no-snow simulations due to the neglect of snow sublimation. With coupled models, the enhanced latent heat flux after precipitation events can be sourced from the surface ice sublimation, snow sublimation, and increased surface soil moisture, while the simple BCD model cannot provide the realistic partition of surface latent heat flux. The ACD model, with its physical consideration of vapor flow, thermal effect on water flow, and snowpack, can identify relative contributions of different components (e.g., thermal or isothermal liquid and vapor flow) to the total mass transfer fluxes. With the ACD-air model, the relative contribution of each component (mainly the isothermal liquid and vapor flows) to the mass transfer was significantly altered during the soil thawing period.
\end{abstract}




\section{Introduction}

35 In cold regions, the snowpack has a profound effect on hydrology and surface energy through its modification of the surface albedo, roughness and insulating property (Boone and Etchevers, 2001; Zhang, 2005). Different than rainfall, precipitation water of snowfall enters the soil with a significant lag in time. However, a large and sudden outflow or runoff may be produced because of the snowmelt effect. The heat insulating effect of snow cover also provides a buffer layer to reduce the magnitude of the underlying subsurface temperature and thus markedly affect the thickness of the active layer in cold regions. The effect of snow cover on the subsurface soils has been studied and reviewed (e.g., Zhang, 2005; Hrbáček et al., 2016). For instance, snow cover can act as an insulator between atmosphere and soil with its low thermal conductivity (Zhang, 2005; Hrbáček et al., 2016). The snowmelt functions as the energy sink with the absorption of heat due to phase change (Zhang, 2005). Yi et al. (2015) investigated the seasonal snow cover effect on soil freezing/thawing process and its related carbon implications. Such studies mainly focus on the thermal effect of snowpack on the frozen soils, however, the effect of snowpack on the soil water and vapor transfer process is rarely reported (Hagedorn et al., 2007; Iwata et al., 2010; Domine et al., 2019).

Great amounts of modeling efforts have been made to better reproduce the snowpack characteristic and its effects. Initially, snowpack dynamics was expressed as a simple empirical function of temperature.

50 Nevertheless, these empirical relations have limited applications in complex climate conditions (Pimentel et al., 2015). Many physically-based models for the mass and energy balance in the snowpack have been developed for their coupling with hydrological models or atmospheric models. Boone and Etchevers (2001) divided these snow models into three main categories: i) simple force-restore schemes with the snow modeled as the composite snow-soil layer (Pitman et al., 1991; Douville et al., 1995; Yang et al., 1997) or a single explicit snow layer (Verseghy, 1991; Tarboton and Luce, 1996; Slater et al., 1998; Sud and Mocko, 1999; Dutra et al., 2010); ii) detailed internal-snow-process schemes with multiple snow layers of fine vertical resolution (Jordan, 1991; Lehning et al., 1999; Vionnet et al., 2012; Leroux and Pomeroy, 2017); iii) intermediate-complexity schemes with physics from the detailed schemes but with a limited amount of layers, which are intended for coupling with atmospheric models (e.g., Sun et al., 1999; Boone and Etchevers, 2001).

60 The intercomparison results of the abovementioned snow models at an alpine site indicated that all three types of schemes are capable of representing the basic features of the snow cover over the 2-yr period but behaved differently on shorter timescales. Furthermore, Snow Model Intercomparison Project (SnowMIP) at two mountainous alpine sites revealed that the albedo parameterization was the major factor influencing the simulation of net shortwave radiation, which was independent of model complexity (Etchevers et al., 2004) but affect directly snow simulations. SnowMIP2 evaluated thirty-three snowpack models across a wide range of hydrometeorological and forest canopy conditions, identified the shortcomings of different snow models and highlighted the necessity of studying the separate contribution of individual components to the mass and energy balance of snowpack (Rutter et al., 2009). With the majority of research focuses on the intercomparison of the snowpack models with various physical complexity, little attention has been paid to 
70 the treatment of the underlying soil physical process (see the brief overview of the current soil-snow modelling efforts in Table 1).

In this paper, one of the widely used snowpack model (Utah energy balance snowpack model, UEB, Tarboton and Luce, 1996) was incorporated into a common soil modeling framework (Simultaneous Transfer of Energy, Mass and Momentum in Unsaturated Soils with Freeze-Thaw, STEMMUS-FT, Zeng et al., 2011a, b; Zeng and Su, 2013; Yu et al., 2018), with various levels of model complexity, in terms of mass and energy transport physics. We utilized in situ observations and numerical experiments to investigate the effect of snowpack on the underlying soil mass transfer with different complexities of soil models. The description of the coupled soil-snow modeling framework and the model setup for this study are presented in Section 2. Section 3 verified the proposed model and identified the effect of snowpack on soil liquid/vapor fluxes. The uncertainties and limitations of this study, and the benefits we can obtain from the proposed model (i.e., the effect of snowpack on the coupled mass and energy transport in the soil) is discussed in Section 4.

\section{Description of Coupled Soil-Snow Modelling Framework and Model Setup}

\subsection{Soil mass and heat transfer model}

The detailed physically based two-phase flow soil model (STEMMUS) was first developed to investigate the underlying physics of soil water, vapor, and dry air transfer mechanisms and their interaction with the atmosphere (Zeng et al., 2011a, b; Zeng and Su, 2013). It is realized by simultaneously solving the balance equations of soil mass, energy, and dry air in a fully coupled way. The mediation effect of vegetation on such interaction was latterly incorporated via the root water uptake sub-module (Yu et al., 2016) and furthermore by coupling with the detailed soil and vegetation biogeochemical process (Wang et al., 2020; Yu et al., 2020a). Implementing the freeze-thaw process (hereafter STEMMUS-FT, for applications in cold regions), it facilitates our understanding of the hydrothermal dynamics of respective components in frozen soil medium (i.e., soil liquid water, water vapor, dry air, and ice) (Yu et al., 2018; Yu et al., 2020c).

In response to minimizing the potential model-comparison uncertainties rising from various model structures (Clark et al., 2015) and to figure out which process matters, three levels of complexity of mass and heat transfer physics are made available in the current STEMMUS-FT modelling framework (Yu et al., 2020c). First, the 1-D Richards equation and heat conduction were deployed in STEMMUS-FT to describe the isothermal water flow and heat flow (termed BCD). In the BCD model, the interaction of soil water and heat transfer is only implicitly via the parameterization of heat capacity, thermal conductivity and the water phase change effect. For the advanced coupled water and heat transfer (ACD model), the water flow is affected by soil temperature regimes. The movement of water vapor, as the linkage between soil water and heat flow, is explicitly characterized. STEMMUS-FT further enables the simulation of temporal dynamics of three water phases (liquid, vapor and ice), together with the soil dry air component (termed ACD-air model). The governing equations of liquid water flow, vapor flow, air flow, and heat flow were listed in Appendix A.1 
(see the more detailed model description in Zeng et al., 2011a, b; Zeng and Su, 2013; Yu et al., 2018; Yu et

\subsection{Snowpack module UEB}

The Utah energy balance (UEB) snowpack model (Tarboton and Luce, 1996) is a single-layer physicallybased snow accumulation and melt model. The snowpack is characterized using two primary state variables, snow water equivalent $S W E$ and the internal energy $U$. Snowpack temperature is expressed diagnostically as the function of $S W E$ and $U$, together with the states of snowpack (i.e., solid, solid and liquid mixture, and liquid). Given the insulation effect of the snowpack, snow surface temperature differs from the snowpack bulk temperature, which is mathematically considered using the equilibrium method (i.e., balances energy fluxes at the snow surface). The age of the snow surface, as the auxiliary state variable, is utilized to calculate snow albedo (see Appendix A.3). The melt outflow is calculated using Darcy's law with the liquid fraction

115 as inputs. The conservation of mass and energy, as presented in Appendix A.2, forms the physical basis of UEB (Tarboton and Luce, 1996).

UEB is recognized as one simple yet physically-based snowmelt model, which can capture the first order snow process (e.g., diurnal variation of meltwater outflow rate, snow accumulation, and ablation, see a general overview of UEB model development and applications in Table S3). It requires little effort in parameter calibration and can be easily transportable and applicable to various locations (e.g., Gardiner et al., 1998; Schulz and de Jong, 2004; Watson et al., 2006; Sultana et al., 2014; Pimentel et al., 2015; Gichamo and Tarboton, 2019) especially for data scarce regions as for example Tibetan Plateau. We thus selected the original parsimonious UEB (Tarboton and Luce, 1996) as the snow module to be coupled with soil module (STEMMUS-FT).

\section{$125 \quad 2.3$ Coupling procedure}

The coupled process between the snowpack model (UEB) and the soil water model (STEMMUS-FT) was illustrated in Figure 1. The one-way sequential coupling is employed to couple the soil model with the current snowpack model. The role of the snowpack is explicitly considered by altering the water and heat flow of the underlying soil. The snowpack model takes the atmospheric forcing as the input (precipitation, air temperature, wind speed and direction, relative humidity, shortwave and longwave radiation) and solves the snowpack energy and mass balance (Eq. A.8 \& A.9, Subroutines: ALBEDO, PARTSNOW, PREDICORR), provides the melt water flux and heat flux as the surface boundary conditions for the soil model STEMMUSFT (Subroutines: h_sub and Enrgy_sub for ACD models; Diff_Moisture_Heat for BCD model). STEMMUS-FT then solves the energy and mass balance equations of soil layers in one timestep. To highlight 135 the effect of snowpack on the soil water and vapor transfer process, we constrained the soil surface energy boundary as the Dirichlet type condition (take the specific soil temperature as the surface boundary condition). Surface soil temperature was derived from the soil profile measurements and not permitted to be higher than 
zero when there is snowpack. To ensure the numerical convergence, the adapted timestep strategy was used. The half-hourly meteorological forcing measurements were linearly interpolated to the running timesteps (Subroutine Forcing_PARM). The precipitation rate (validated at 3-hour time intervals) was regarded uniformly within the 3-hour duration (see Table S1 for detail). The general description of the main subroutines in STEMMUS-UEB, including the main functions, input/output, and its connection with other subroutines, was presented in Table 2 (linked with Table S1 and S2 for the description of model input parameters and outputs for this study, see the detailed general description in Tarboton and Luce, 1996; Zeng and Su, 2013; Yu et al., 2018).

\subsection{Configurations of numerical experiments}

On the basis of the aforementioned STEMMUS-UEB coupling framework, the various complexity of vadose zone physics was further implemented as three alternative model versions. First, the soil ice effect on soil hydraulic and thermal properties, and the heat flow due to the water phase change were taken into account, while the water and heat transfer is not coupled in STEMMUS-FT and termed BCD model. Second, the STEMMUS-FT with the fully coupled water and heat transfer physics (i.e., water vapor flow and thermal effect on water flow) was applied and termed ACD model. Lastly, on top of ACD model, the air pressure was independently considered as a state variable (therefore, the airflow) and termed ACD-air model. With the abovementioned model versions (STEMMUS-FT_Snow) and taking into account the no-snow scenarios (STEMMUS-FT_No-Snow), Table 3 lists the configurations of all six designed numerical experiments. The model parameters used for all simulations for the tested experimental site are listed in Table S2.

\subsection{Description of the Tested Experimental site}

Maqu station, equipped with a catchment scale soil moisture and soil temperature (SMST) monitoring network and micro-meteorological observing system, is situated on the north-eastern edge of the Tibetan Plateau (Su et al., 2011; Dente et al., 2012; Zeng et al., 2016). According to the updated Köppen-Geiger climate Classification System, it can be characterized as a cold climate with dry winter and warm summer. The average annual air temperature is $1.2{ }^{\circ} \mathrm{C}$, and the mean air temperatures of the coldest month (January) and warmest month (July) are about $-10.0^{\circ} \mathrm{C}$ and $11.7^{\circ} \mathrm{C}$, respectively. Alpine meadows (e.g., Cyperaceae and Gramineae), with a height varying from $5 \mathrm{~cm}$ to $15 \mathrm{~cm}$ throughout the growing season, are the dominant land cover in this region. The general soil types are sandy loam, silt loam and organic soil for the upper soil layers (Dente et al., 2012; Zheng et al., 2015; Zhao et al., 2018). The soil texture and hydraulic properties were listed in Table S2 and how it used in STEMMUS-UEB is illustrated in Figure 1 and Table 2.

The Maqu SMST monitoring network spans an area of approximately $40 \mathrm{~km} \times 80 \mathrm{~km}$ with the elevation ranging from $3200 \mathrm{~m}$ to $4200 \mathrm{~m}$ a.s.l. $\left(33^{\circ} 30^{\prime}-34^{\circ} 15^{\prime} \mathrm{N}, 1^{\circ} 1^{\circ} 38^{\prime}-102^{\circ} 45^{\prime} \mathrm{E}\right)$. SMST profiles are automatically measured by $5 \mathrm{TM} \mathrm{ECH} \mathrm{E}_{2} \mathrm{O}$ probes (METER Group, Inc., USA) installed at different soil depths, i.e., $5 \mathrm{~cm}, 10 \mathrm{~cm}, 20 \mathrm{~cm}, 40 \mathrm{~cm}$, and $80 \mathrm{~cm}$. The micro-meteorological observing system consists of a $20 \mathrm{~m}$ Planetary Boundary Layer (PBL) tower providing the meteorological measurements at five heights above 
ground (i.e., wind speed and direction, air temperature and relative humidity), and an eddy-covariance system (EC150, Campbell Scientific, Inc., USA) equipped for measuring the turbulent sensible and latent heat fluxes and carbon fluxes. The equipment for four-component down and upwelling solar and thermal radiation (NR01-L, Campbell Scientific, Inc., USA), and liquid precipitation (T200B, Geonor, Inc., USA) are also deployed. The dataset from December 1, 2015 to March 15, 2016 was utilized in this study. An independent precipitation data (3-hour time interval) during the same testing period from an adjacent meteorological station was used as the mutual validation data.

\section{Results: Comparison of simulation results of surface variables with/without snowpack effect}

\subsection{Albedo}

The time series of surface albedo, calculated as the ratio of upwelling shortwave radiation to the downwelling shortwave radiation and estimated using BCD, ACD and ACD-air models, was shown in Figure 2 with precipitation. As the snowpack has a higher albedo than the underlying surface (e.g., soil, vegetation), compared to the observations, models without snow module presented a relatively flat variation of daily average surface albedo, and lacked the response to the winter precipitation events (Figure 2, Table 4). With the snow module, STEMMUS-UEB models can capture mostly the abrupt increase of surface albedo after winter precipitation events. The mismatches in terms of the magnitude or absence of increased albedo after precipitation events indicated that the model tended to underestimate the dynamics of albedo and the shallow snowfall events might be not well captured by the model (see the Sect. 4.1). Three model versions (BCDSnow, ACD-Snow, and ACD-air-Snow) produced similar fluctuations regarding the presence of snow cover with slight differences in terms of the magnitude of albedo.

\subsection{Soil Temperature and Moisture Dynamics}

The observed spatial and temporal dynamics of soil temperature from five soil layers was used to verify the performance of different models (Fig. 3). The initial soil temperature state can be characterized as the warm bottom and cool surface soil layers. The freezing front (indicated by the zero degree isothermal line, ZDIL) developed downwards rapidly till $70^{\text {th }}$ day after December 1 , 2015, reaching its maximum depth. Then the freezing front stabilized as the offset effect of latent heat release (termed as zero-curtain effect). Such effect can sustain until all the available water to that layer is frozen, at which point the latent heat effect is negligible compared to the heat conduction. At shallower layers, the atmospheric forcing dominates the fluctuation of thermal states. The isothermal lines (e.g., $-2^{\circ} \mathrm{C}$ ) had a larger variation than that of ZDIL. At deeper soil layers, the temporal dynamics of isothermal lines were smoother than that of ZDIL, indicating that the effect of fluctuated atmospheric force on soil temperature was damped with the increase of soil depth. Compared to the observations, BCD-Snow model presented an earlier development of freezing front and arrival of the maximum freezing depth $\left(60^{\text {th }}\right.$ day after December 1,2015$)$. The deeper and more fluctuated freezing front indicates that a stronger control of atmospheric forcing on soil thermal states was produced by BCD-Snow 
model. The ACD models can well capture the propagation characteristic of freezing front in terms of the variation magnitude and maximum freezing depth. There is no significant difference in soil thermal dynamics between the model with and without snow module, except at the surface soil layers (Table 4).

210 Figure 4 shows the spatial and temporal dynamics of observed and simulated soil water content in the liquid phase (SWCL). The SWCL of active layers is largely dependent on the soil freezing/thawing status. Soil is relatively wet at soil layers of $10-60 \mathrm{~cm}$ for the starting period. Its temporal development was disrupted by the presence of soil ice and tended to increase wetness during the thawing period. A relatively dry zone $\left(\theta_{L}<\right.$ $0.06 \mathrm{~m}^{3} \mathrm{~m}^{-3}$ ) above the freezing front was found, indicating the nearly completely frozen soil during the stabilization stage. The initial wet zone of soil moisture was narrowed down and the rewetting zone tended to enlarge from BCD-Snow simulations due to its early freezing and thawing of soil (Fig. 4b). The position of the dry zone occurred earlier as the early reaching of the stabilization period by BCD-Snow model (Fig. $3 b)$. For the ACD models, the position and development of initial wet zone, rewetting zone and the dry zone is similar to that from the observations, indicating the soil moisture dynamics can be well captured by the

220 ACD models. Compared to STEMMUS-FT_Snow model, there was no observable difference in the SWCL dynamics at deeper soil layers from STEMMUS-FT_No-Snow simulations. The surface SWCL was found affected from STEMMUS-FT_Snow simulations (Table 4).

\subsection{Surface Latent Heat Flux}

Figure 5 shows the comparison of time series of observed and model simulated surface cumulative latent heat flux using three models with/without consideration of snow module. Considerable overestimation of latent heat flux was produced by the BCD-Snow model, with $121.79 \%$ more than observed. Such overestimations were largely reduced by ACD and ACD-air models. There is a slight underestimation of cumulative latent heat flux by ACD-Snow and ACD-air-Snow models, with -8.33\% and -7.05\%, respectively. Compared with STEMMUS-FT_Snow simulations, there is less latent heat flux produced by STEMMUS-

230 FT_No-snow simulations. It is mainly due to the sublimation of snow cover, which cannot be simulated by the STEMMUS-FT_No-snow models. The difference in cumulative latent heat flux between STEMMUSFT with and without snow module increases from BCD to ACD-air schemes, with the values of 2.02\%, 7.69\%, and $8.97 \%$ for BCD, ACD and ACD-air schemes, respectively.

\subsection{Liquid/vapor fluxes}

235 To further elaborate the effect of snowpack on LE, we presented the diurnal variations of LE and its components at two typical episodes with precipitation events (freezing and thawing period, respectively). The relative contribution of liquid and vapor flow to the total mass transfer after precipitation events was separately presented in Figure 6 \& 7, i.e., the liquid water flux driven by temperature $q_{L T}$, matric potential $q_{L h}$ and air pressure $q_{L a}$, water vapor flux driven by temperature $q_{V T}$, matric potential $q_{V h}$ and air pressure $q_{V a}$. 


\subsubsection{Freezing period}

Diurnal dynamics of observed and simulated latent heat flux during the rapid freezing period with the occurrence of precipitation events, from $10^{\text {th }}$ to $14^{\text {th }}$ Days after Dec. 1. 2015, is shown as Fig. 6a, d \&g. Compared to the observations, the diurnal variations of latent heat flux was captured by the proposed model with various levels of complexities. Performance of BCD, ACD, and ACD-air models in simulating LE

245 differed mainly regarding the magnitude and response to precipitation events. For the BCD-Snow model, the overestimation of LE was found at $10^{\text {th }}$ and $11^{\text {th }}$ day after December 1 due to relatively high surface soil moisture simulations (Fig. S1b). A certain amount of enhanced surface evaporation was produced shortly after precipitation, which is most probably due to the snow sublimation, which presents in the model simulations while not intuitively in observations. The mismatch in the LE enhancement after precipitation events can be attributed to that the partition process of precipitation into various components (rainfall, snowfall, canopy interception) might not be well captured by the model. Such a response to the winter precipitation events was absent from the BCD-No-Snow simulations.

The overestimation of LE was reduced by ACD and ACD-air models (Fig. 6d \& g). Compared to ACD-Snow model simulations, ACD-No-snow model produced a stronger diurnal variation of LE after the precipitation, and is more approaching to the measured LE. The lower diurnal variation of LE for ACD-Snow model can be ascribed to the lower surface SWCL (see Fig. S1d \& g). For ACD-Snow model, precipitation was partitioned into rainfall and snowfall, part of which was directly evaporated as sublimation. The sum of rainfall and the melting part of snowfall reached the soil surface as the incoming water flux, which is less than that for the ACD-No-snow model (took all the precipitation as the incoming water flux). There is no significant difference in the dynamics of LE between simulations by ACD models and ACD-air models.

During the freezing period, the soil water vapor, instead of liquid water flux, dominated the surface mass transfer process. Missing the description of the vapor diffusion process hindered the BCD models to realistically depict the decomposition of surface mass transfer dynamics.

From the ACD model, there is a visible diurnal variation of thermal vapor flux $q_{V T}$. It can be clearly identified that the isothermal vapor flux $q_{V h}$ contributed to most of the mass transfer during the freezing period. After winter precipitation during the nighttime, there is a certain amount of isothermal vapor flux driven by the downward matric potential gradient. The reason is that the precipitation water immediately freezes on the soil surface. It should be noted that the sum of water/vapor fluxes at $0.1 \mathrm{~cm}$ soil layer cannot balance the surface evaporation especially after the precipitation events (Fig. 6e). We assumed and attributed it to the surface ice sublimation process. Precipitation water was frozen on the soil surface, and only vapor exists in the topsoil layers. Sublimation of surface ice may contribute to the gaps between liquid/vapor fluxes and LE (Yu et al., 2018). As more precipitation water was frozen on the soil surface from ACD-No-Snow model, the difference between the sum of water/vapor fluxes at $0.1 \mathrm{~cm}$ soil layer and the surface evaporative water enlarged compared to ACD-Snow simulations (Fig. 6f). Thermal liquid water flux appears negligible to the 
275 total mass flux during the whole simulation period. There is no significant difference recognized in the mass transfer between the ACD-air and ACD during the freezing period.

\subsubsection{Thawing period}

During the thawing period, the diurnal variations of LE were well simulated by the models. There are some discrepancies regarding the peak values of LE. For BCD-Snow model, overestimations were found in $101^{\text {st }}$, $102^{\text {nd }}$, and $103^{\text {rd }}$ day after December 1,2015 . The high LE values on $101^{\text {st }}$ and $102^{\text {nd }}$ day are probably due to the thawing water (Fig. S2b) while on $103^{\text {rd }}$ day it is the snow sublimation (Fig. 7a). The peak values were reproduced but shifted by BCD-No-Snow simulations, which occurred on $100^{\text {th }}$ and at the end of $102^{\text {nd }}$, indicating the shift of surface soil moisture states (Fig. S2b).

For the ACD model, the difference in latent heat flux between snow and no-snow simulations was noticeable

285 two days after precipitation. The larger values of LE from ACD-Snow model occurred earlier than that from ACD-No-snow model, as the earlier response of surface soil moisture to the precipitation event (Fig. S2). While compared to the observations, the enhancement of LE advanced from the ACD-Snow simulations (Fig. 7d). There are mismatches in the time and magnitude of LE enhancement between ACD-Snow model simulations and observations. This discrepancy lies in the uncertainties of snowpack simulations, which can

290 be due to either the inaccurate precipitation measurements (Barrere et al., 2017; Günther et al., 2019) or that the precipitation partition process is not well described by the model (Harder and Pomeroy, 2014; Ding et al., 2017).

For ACD-Snow model, the precipitation induced evaporation enhancement was lagged compared to ACDNo-Snow model. This enhanced evaporation can be attributed to the snow sublimation and increased surface

295 soil moisture content. The similar lag behavior of precipitation-enhanced evaporation was produced by the ACD-air-Snow models.

During the thawing period, a certain amount of upward liquid water flux was produced by BCD model, supplying the water to evaporate into the atmosphere (Fig. 7b \&c). Compared to the isothermal liquid flux, the thermal liquid flux was negligible to the total mass flux.

300 For the ACD model, the diurnal variation of thermal vapor flux $q_{V T}$ was enhanced after precipitation, producing a larger amount of upward/downward vapor flux during the night/day time (e.g., Fig. 7e). As the surface soil is relatively dry, the isothermal vapor flux contributes nearly all of the mass flux during the thawing period. Driven by the large downward matric potential gradient, a large amount of isothermal water vapor flux, accompanied by downward liquid water flux, can be found after the nighttime precipitation event.

305 This precipitation induced isothermal liquid/vapor flux was lagged and less intense from ACD-Snow model than that from ACD-No-Snow model. The snowpack reduces the instant liquid phase of precipitation and snowmelt will occur afterward. It resulted in the lagged and weaker response of surface SWCL to the precipitation (Fig. S2). It breaks the balance between isothermal vapor flux and evaporative LE. Compared 
to ACD-No-Snow model, such imbalance was enlarged for ACD-Snow model during the thawing period

Compared to the ACD-No-Snow simulations, the upward thermal vapor flux was enhanced after precipitation for the ACD-air-No-Snow model (Fig. 7i). This enhanced upward vapor flux reduced the soil liquid water content at $0.1 \mathrm{~cm}$ (Fig. S2f), and decreased the soil hydraulic conductivity and then the downward isothermal liquid/vapor flux. Other than that, there is no significant difference between the ACD-air model and ACD model during the thawing period.

\section{Discussion}

\subsection{Uncertainties of surface albedo simulations and Limitations}

After winter precipitation, land surface albedo increases considerably (Fig. 2), indicating the formation of the snowpack. While such snowfall events were isolated with small magnitude, which are difficult to be well captured. Such difficulties can be partially attributed to the uncertainties in the representativity of precipitation measurements. Due to the spatial variability of precipitation, the accurate observation of winter precipitation is proved to be a challenge, especially during windy winters (Barrere et al., 2017; Pan et al., 2017). On the other hand, the temporal resolution of precipitation measurements adopted in this study is relatively coarse (3-hour). In the current precipitation partition parameterization, the amount of snowfall was determined as a function of precipitation and air temperature thresholds. Given the coarse temporal resolution of precipitation measurements, the model may produce a time shift of snowfall events or even the malidentification of snowfall taken into account the effect of air temperature. The other uncertainty lies in the representation of the snow process. For example, the wind-blow effect and canopy snow interception, which have been recognized as important to the accurate simulation of snowpack dynamics (Mahat and Tarboton, 2014), are not taken into account in detail. Last but not least, the interpretation of surface albedo dynamics needs to be adapted to the specific site, especially regarding the shallow snow situations (Ueno et al., 2007; Ueno et al., 2012; Ding et al., 2017; Wang et al., 2017). The albedo of the underlying surface should also be properly accommodated to this Tibetan meadow system. Regardless of the aforementioned uncertainties, our proposed model was capable to capture the surface albedo variations with precipitation (Fig. 2) and can be seen acceptable to conduct the analysis of snow cover effects in such a harsh condition.

\subsection{Benefits from STEMMUS-UEB: The effect of snow cover}

Different from the rainfall, precipitation water from snowfall enters the soil considerably lagged in time due to the storage by the snow cover (You et al., 2019). With consideration of snow module, precipitation was partitioned into rainfall and snowfall. Part of the snowfall evaporated into the atmosphere as sublimation and the other part together with the rainfall infiltrated into the underlying soil. It resulted in the delay of incoming water to the soil with a less amount compared to that without consideration of snow module (Fig. 8 e \&f). 
This amount of incoming water increased the evaporation after precipitation (Fig. $8 \mathrm{~d}$ ). The other source for the enhanced evaporation flux after precipitation is snow sublimation, which is absent from the model without snow module. Sublimation, although not easy to observe, occurs readily under certain weather conditions (e.g., with freezing temperatures, enough energy). It can be further sped up at regions with low relative humidity, air pressure and dry winds. Such amount of sublimation has been reported important from the perspective of climate and hydrology (e.g., Strasser et al., 2008; Jambon-Puillet et al., 2018), especially at high altitude regions with the low air pressure. During the freezing period, the evaporation enhancement can be also sourced from the sublimation of surface ice. The amount of ice sublimation appeared to be decreased during the freezing period as the presence of transient snowpack (Fig. 6). This is consistent with the results of Hagedorn et al. (2007), who investigated the effect of snow cover on the mass balance of ground ice with an artificially continuous annual snow cover. Their results indicated that snow cover enhanced the vapor transfer into the soil and thus reduced the long term ice sublimation. The relative contribution of increased surface soil moisture, snow sublimation and surface ice sublimation to the enhanced evaporation is dependent on the pre-precipitation soil moisture/temperature states, air temperature and the time and magnitude of precipitation events. Under the conditions of the low pre-precipitation SWCL under the freezing soil temperature (e.g., Fig. 6e, $11^{\text {th }}$ vs. $12^{\text {th }}$ Days after 1 December), the precipitation falls down on the surface as snowfall and rainfall (mostly freezes as ice). The sublimation from surface ice can contribute to most of the total mass transfer (e.g., Fig. 6e, $11^{\text {th }}$ Days after 1 December). If the soil temperature rises above the freezing temperature, there will be no sublimation of surface ice contributing to the enhanced evaporation.

\subsection{Benefits from STEMMUS-UEB: Responses among different complexity of soil model}

The model with various complexity of soil mass and energy transfer physics behaves differently in response to the winter precipitation events. During the freezing period, there is no significant difference in the BCD model simulated soil moisture with/without the snow module. The precipitation water freezes at the soil surface, which cannot be transferred downwards with the BCD model physics. The sublimation, from either the snow or the surface ice, contributes all to the precipitation-enhanced evaporation for the BCD model. As with consideration of vapor flow, the surface ice increases the soil moisture at lower layers via the downward isothermal vapor flux (Fig. 6). The surface ice sublimation and increased soil moisture-induced evaporation enhancement can be clearly identified from ACD model simulations. The role of air flow was negligible to the mass transfer during the freezing period.

When it comes to the thawing period, BCD model produced a certain amount of liquid water flow, contributing considerably to the mass transfer. The obvious fluctuation of SWCL was noticed due to the thawing water and precipitation event. The main source for the increased evaporation was interpreted as isothermal liquid water flow. While for the ACD model, the situation becomes more complex. Thawing surface ice and snowmelt water may coexist at the soil surface, resulting in different soil moisture response to precipitation events. The ice sublimation, snow sublimation, and increased soil moisture all contribute to the evaporation enhancement after precipitation. When considering air flow, dry air interacts with soil ice, 
liquid/vapor water in soil pores (Yu et al., 2018) and alters the soil moisture states. It thus considerably changes the relative contribution of each component to the mass transfer (Fig. 7).

\section{Conclusions}

Rendering from the aim to investigate the hydrothermal effect of the snowpack on the underlying soil system, we developed the integrated process-based soil-snow-atmosphere model, STEMMUS-UEB v1.0.0, which is dedicated for the easily transportable and physically-based description of the snowpack process and the detailed interpretation of the soil physical process with various complexities. From STEMMUS-UEB simulations, snowpack affects not only the soil surface conditions (surface ice and SWCL), energy-related states (albedo, latent heat flux), but also the transfer patterns of subsurface soil liquid/vapor flow. With consideration of the snow module, STEMMUS-FT model can capture mostly the abrupt increase of surface albedo after winter precipitation events. There is a significant overestimation of cumulative surface latent heat flux by BCD model. ACD and ACD-air model produces a slight underestimation of cumulative LE compared to the observations. Given no sublimation from snowpack, there is a less latent heat flux produced by STEMMUS-FT_No-snow simulations compared with STEMMUS-FT_Snow simulations. The presence of snowpack alters the partition process of precipitation and thus the surface SWCL. BCD models with/without snowpack produced the similar surface SWCL during the freezing period while the abrupt increase of soil moisture in response to the precipitation during the thawing period. ACD-Snow model simulated a less intensive and lagged soil moisture response to precipitation compared to the ACD-No-Snow model during the freezing and thawing period, respectively. ACD-air model affects the intensity of increased surface soil moisture, especially during the thawing period. Three mechanisms, surface ice sublimation, snow sublimation and increased soil moisture, can contribute to the enhanced latent heat flux after winter precipitation events. The relative role of each mechanism in the total mass transfer can be affected by the time and magnitude of precipitation and pre-precipitation soil moisture/temperature states (see Sect. 4.3). The simple BCD model cannot provide a realistic partitioning of mass transfer. ACD model, with consideration of vapor diffusion and thermal effect on water flow and snowpack can produce a reasonable analysis of the relative contributions of different water flux components. With consideration of air flow, the relative contribution of each component to the mass transfer was considerably altered during the thawing period. Further work will take into account the thermal interactive effects between snowpack and the underlying soil. Such work will inevitably enhance our confidence in interpreting the underlying mechanisms and physically elaborating on the role of snowpack in cold regions. 
Code and data availability. The coupled Soil-Snow model (STEMMUS-UEB v1.0.0) with three levels of complexity of soil water and heat transfer physics was developed based on STEMMUS-FT (Simultaneous Transfer of Energy, Momentum and Mass in Unsaturated Soils with Freeze and Thaw) and UEB (Utah Energy Balance) model. The original STEMMUS source code is available from the GitHub website via https://github.com/yijianzeng/STEMMUS. The snowmelt module is based on the code of (Tarboton and Luce, 1996). The coupled STEMMUS-UEB v1.0.0 code is archived on Zenodo (Yu et al., 2020b), licensed under the Apache License, Version 2.0. The current code is tested by MATLAB 2019b using an Intel Core i7 processor (Intel ${ }^{\circledR}$ Core ${ }^{\mathrm{TM}} \mathrm{i} 7-6700 \mathrm{HQ}$ CPU @ 2.60GHz 2.59 GHz), an installed memory (RAM, 16.0 GB), and a 64-bit Windows 10 Enterprise operating system. The relevant data can be accessed from 4TU. Center for Research Data (https://doi.org/10.4121/uuid:cc69b7f2-2448-4379-b638-09327012ce9b; https://doi.org/10.4121/uuid:61db65b1-b2aa-4ada-b41e-61ef70e57e4a).

Author contribution. ZS, YZ, and LY designed and conceptualized this study; YZ and ZS provided the original version of STEMMUS model code and supervised the further modelling development; LY developed the STEMMUS-UEB model coupling framework with the contribution from YZ; LY and YZ prepared the original draft of the paper, LY, YZ, and ZS all contributed to the reviewing and editing of the final paper.

Competing interests. The authors declare that they have no conflict of interest.

\section{Acknowledgment}

430 This work is supported by the National Natural Science Foundation of China (grant no. 41971033) and supported by the Fundamental Research Funds for the Central Universities, CHD (grant no. 300102298307). The authors thank the editor and referees very much for their constructive comments and suggestions on improving the manuscript. 


\section{Appendix A}

\section{A.1 STEMMUS-FT model with three levels of complexity}

\section{A.1.1 Uncoupled soil water and heat transfer physics}

The Richard equation which describes the water flow under gravity and capillary forces in isothermal conditions, is solved for variably saturated soils.

$$
\frac{\partial \theta}{\partial t}=-\frac{\partial q}{\partial z}-S=\rho_{L} \frac{\partial}{\partial z}\left[K\left(\frac{\partial \psi}{\partial z}+1\right)\right]-S
$$

where $\theta\left(\mathrm{m}^{3} \mathrm{~m}^{-3}\right)$ is the volumetric water content; $q\left(\mathrm{~kg} \mathrm{~m}^{-2} \mathrm{~s}^{-1}\right)$ is the water flux; $z(\mathrm{~m})$ is the vertical direction coordinate (positive upwards); $S\left(\mathrm{~s}^{-1}\right)$ is the sink term for root water uptake; $\rho_{L}\left(\mathrm{~kg} \mathrm{~m}^{-3}\right)$ is the soil liquid water density; $K\left(\mathrm{~m} \mathrm{~s}^{-1}\right)$ is the soil hydraulic conductivity; $\psi(\mathrm{m})$ is the soil water potential; $t(\mathrm{~s})$ is the time.

The heat conservation equation, considering the latent heat due to water phase change, can be expressed as:

$$
C_{\text {soil }} \frac{\partial T}{\partial t}-\rho_{i} L_{f} \frac{\partial \theta_{i}}{\partial t}=\frac{\partial}{\partial z}\left(\lambda_{e f f} \frac{\partial T}{\partial z}\right)
$$

where $C_{\text {soil }}\left(\mathrm{J} \mathrm{kg}^{-1}{ }^{\circ} \mathrm{C}^{-1}\right)$ is the specific heat capacity of bulk soil; $T\left({ }^{\circ} \mathrm{C}\right)$ is the soil temperature; $\rho_{i}\left(\mathrm{~kg} \mathrm{~m}^{-3}\right)$ is the density of soil ice; $L_{f}\left(\mathrm{~J} \mathrm{~kg}^{-1}\right)$ is the latent heat of fusion; $\theta_{i}\left(\mathrm{~m}^{3} \mathrm{~m}^{-3}\right)$ is the soil ice volumetric water content. $\lambda_{\text {eff }}\left(\mathrm{W} \mathrm{m}^{-1}{ }^{\circ} \mathrm{C}^{-1}\right)$ is the effective thermal conductivity of the soil;

\section{A.1.2 Coupled water and heat transfer}

For the coupled water and heat transfer physics, the liquid water flow is non-isothermal and affected by soil temperature regimes. The movement of water vapor, as the linkage between soil water and heat flow, is explicitly characterized. With modifications made by Milly (1982), the extended version of Richards (1931) equation with consideration of the liquid and vapor flow is written as:

$$
\begin{aligned}
& \frac{\partial}{\partial t}\left(\rho_{L} \theta_{L}+\rho_{V} \theta_{V}+\rho_{i} \theta_{i}\right)=-\frac{\partial}{\partial z}\left(q_{L}+q_{V}\right)-S \\
& =-\frac{\partial}{\partial z}\left(q_{L h}+q_{L T}+q_{V h}+q_{V T}\right)-S \\
& =\rho_{L} \frac{\partial}{\partial z}\left[K_{L h}\left(\frac{\partial \psi}{\partial z}+1\right)+K_{L T} \frac{\partial T}{\partial z}\right]+\frac{\partial}{\partial z}\left[D_{V h} \frac{\partial \psi}{\partial z}+D_{V T} \frac{\partial T}{\partial z}\right]-S
\end{aligned}
$$

where $\rho_{V}$ and $\rho_{i}\left(\mathrm{~kg} \mathrm{~m}^{-3}\right)$ are the density of water vapor and ice, respectively; $\theta_{\mathrm{L}}$ and $\theta_{V}\left(\mathrm{~m}^{3} \mathrm{~m}^{-3}\right)$ are the volumetric water content (liquid and vapor, respectively); $q_{L}$ and $q_{V}\left(\mathrm{~kg} \mathrm{~m}^{-2} \mathrm{~s}^{-1}\right)$ are the soil water fluxes of liquid water and water vapor (positive upwards), respectively. $K_{L h}\left(\mathrm{~m} \mathrm{~s}^{-1}\right)$ and $K_{L T}\left(\mathrm{~m}^{2} \mathrm{~s}^{-1}{ }^{\circ} \mathrm{C}^{-1}\right)$ are the isothermal and thermal hydraulic conductivities, respectively. $D_{V h}\left(\mathrm{~kg} \mathrm{~m}^{-2} \mathrm{~s}^{-1}\right)$ is the isothermal vapor conductivity; and $D_{V T}\left(\mathrm{~kg} \mathrm{~m}^{-1} \mathrm{~s}^{-1}{ }^{\circ} \mathrm{C}^{-1}\right)$ is the thermal vapor diffusion coefficient.

On the basis of De Vries (1958) and Hansson et al. (2004)'s work, the heat transport function in frozen soils, considering the fully coupled water and heat transport physics, can be expressed as:

$$
\begin{array}{r}
\frac{\partial}{\partial t}\left[\left(\rho_{s} \theta_{s} C_{s}+\rho_{L} \theta_{L} C_{L}+\rho_{V} \theta_{V} C_{V}+\rho_{i} \theta_{i} C_{i}\right)\left(T-T_{r}\right)+\rho_{V} \theta_{V} L_{0}-\rho_{i} \theta_{i} L_{f}\right]-\rho_{L} W \frac{\partial \theta_{L}}{\partial t} \\
=\frac{\partial}{\partial z}\left(\lambda_{e f f} \frac{\partial T}{\partial z}\right)-\frac{\partial}{\partial z}\left[q_{L} C_{L}\left(T-T_{r}\right)+q_{V}\left(L_{0}+C_{V}\left(T-T_{r}\right)\right)\right]-C_{L} S\left(T-T_{r}\right)
\end{array}
$$

where $C_{s}, C_{L}, C_{V}$ and $C_{i}\left(\mathrm{~J} \mathrm{~kg}^{-1}{ }^{\circ} \mathrm{C}^{-1}\right)$ are the specific heat capacities of solids, liquid and water vapor and ice, respectively; $\rho_{s}\left(\mathrm{~kg} \mathrm{~m}^{-3}\right)$ is the density of solids; $\theta_{s}$ is the volumetric fraction of solids in the soil; $T_{r}\left({ }^{\circ} \mathrm{C}\right)$ is 
460 the arbitrary reference temperature; $L_{0}\left(\mathrm{~J} \mathrm{~kg}^{-1}\right)$ is the latent heat of vaporization of water at the reference temperature $T_{r} ; W\left(\mathrm{~J} \mathrm{~kg}^{-1}\right)$ is the differential heat of wetting (the amount of heat released when a small amount of free water is added to the soil matrix).

\section{A.1.3 Coupled mass and heat physics with air flow}

In STEMMUS-FT, the temporal dynamics of three phases of water (liquid, vapor and ice), together with the soil dry air component are explicitly presented and simultaneously solved by spatially discretizing the corresponding governing equations of liquid water flow, vapor flow and air flow.

$$
\begin{aligned}
& \frac{\partial}{\partial t}\left(\rho_{L} \theta_{L}+\rho_{V} \theta_{V}+\rho_{i} \theta_{i c e}\right)=-\frac{\partial}{\partial z}\left(q_{L h}+q_{L T}+q_{L a}+q_{V h}+q_{V T}+q_{V a}\right)-S \\
& =\rho_{L} \frac{\partial}{\partial z}\left[K\left(\frac{\partial \psi}{\partial z}+1\right)+D_{T D} \frac{\partial T}{\partial z}+\frac{K}{\gamma_{w}} \frac{\partial P_{g}}{\partial z}\right]+\frac{\partial}{\partial z}\left[D_{V h} \frac{\partial \psi}{\partial z}+D_{V T} \frac{\partial T}{\partial z}+D_{V a} \frac{\partial P_{g}}{\partial z}\right]-S
\end{aligned}
$$

where $q_{L h}, q_{L T}$, and $q_{L a}\left(\mathrm{~kg} \mathrm{~m}^{-2} \mathrm{~s}^{-1}\right)$ are the liquid water fluxes driven by the gradient of matric potential $\frac{\partial \psi}{\partial z}$, temperature $\frac{\partial T}{\partial z}$, and air pressure $\frac{\partial P g}{\partial z}$, respectively. $q_{V h}, q_{V T}$, and $q_{V a}\left(\mathrm{~kg} \mathrm{~m}^{-2} \mathrm{~s}^{-1}\right)$ are the water vapor fluxes driven by the gradient of matric potential $\frac{\partial \psi}{\partial z}$, temperature $\frac{\partial T}{\partial z}$, and air pressure $\frac{\partial P_{g}}{\partial z}$, respectively. $P_{g}(\mathrm{~Pa})$ is the mixed pore-air pressure. $\gamma_{W}\left(\mathrm{~kg} \mathrm{~m}^{-2} \mathrm{~s}^{-2}\right)$ is the specific weight of water; $D_{T D}\left(\mathrm{~kg} \mathrm{~m}^{-1} \mathrm{~s}^{-1}{ }^{\circ} \mathrm{C}^{-1}\right)$ is the transport coefficient for adsorbed liquid flow due to temperature gradient; $D_{V h}\left(\mathrm{~kg} \mathrm{~m}^{-2} \mathrm{~s}^{-1}\right)$ is the isothermal vapor conductivity; and $D_{V T}\left(\mathrm{~kg} \mathrm{~m}^{-1} \mathrm{~s}^{-1}{ }^{\circ} \mathrm{C}^{-1}\right)$ is the thermal vapor diffusion coefficient; $D_{V a}$ is the advective vapor transfer coefficient (Zeng et al., 2011a, b).

STEMMUS-FT takes into account different heat transfer mechanisms, including heat conduction $\left(\lambda_{\text {eff }} \frac{\partial T}{\partial z}\right)$, convective heat transferred by liquid flux $\left(-C_{L} q_{L}\left(T-T_{r}\right),-C_{L} S\left(T-T_{r}\right)\right)$, vapor flux $\left(-\left[L_{0} q_{V}+\right.\right.$ $\left.\left.C_{V} q_{V}\left(T-T_{r}\right)\right]\right)$ and air flow $\left(q_{a} C_{a}\left(T-T_{r}\right)\right.$ ). The latent heat of vaporization $\left(\rho_{V} \theta_{V} L_{0}\right)$, the latent heat of freezing/thawing $\left(-\rho_{i} \theta_{i} L_{f}\right)$ and a source term associated with the exothermic process of wetting of a porous medium (integral heat of wetting) $\left(-\rho_{L} W \frac{\partial \theta_{L}}{\partial t}\right)$.

$$
\begin{aligned}
& \frac{\partial}{\partial t}\left[\left(\rho_{s} \theta_{s} C_{s}+\rho_{L} \theta_{L} C_{L}+\rho_{V} \theta_{V} C_{V}+\rho_{d a} \theta_{a} C_{a}+\rho_{i} \theta_{i} C_{i}\right)\left(T-T_{r}\right)+\rho_{V} \theta_{V} L_{0}-\rho_{i} \theta_{i} L_{f}\right]- \\
& \rho_{L} W \frac{\partial \theta_{L}}{\partial t} \\
& =\frac{\partial}{\partial z}\left(\lambda_{\text {eff }} \frac{\partial T}{\partial z}\right)-\frac{\partial}{\partial z}\left[q_{L} C_{L}\left(T-T_{r}\right)+q_{V}\left(L_{0}+C_{V}\left(T-T_{r}\right)\right)+q_{a} C_{a}\left(T-T_{r}\right)\right]-C_{L} S\left(T-T_{r}\right)
\end{aligned}
$$

where $\rho_{d a}\left(\mathrm{~kg} \mathrm{~m}^{-3}\right)$ is the density of dry air; $C_{a}\left(\mathrm{~J} \mathrm{~kg}^{-1}{ }^{\circ} \mathrm{C}^{-1}\right)$ is the specific heat capacity of dry air; $q_{a}\left(\mathrm{~kg} \mathrm{~m}^{-}\right.$

${ }^{2} \mathrm{~s}^{-1}$ ) is the air flux. The air flow balance equation for solving the coupled water and heat equations is written as Zeng et al. (2011a, b) and Zeng and Su (2013):

$$
\frac{\partial}{\partial t}\left[\varepsilon \rho_{d a}\left(S_{a}+H_{c} S_{L}\right)\right]=\frac{\partial}{\partial z}\left[D_{e} \frac{\partial \rho_{d a}}{\partial z}+\rho_{d a} \frac{S_{a} K_{g}}{\mu_{a}} \frac{\partial P_{g}}{\partial z}-H_{c} \rho_{d a} \frac{q_{L}}{\rho_{L}}+\left(\theta_{a} D_{V g}\right) \frac{\partial \rho_{d a}}{\partial z}\right]
$$

where $\varepsilon$ is the porosity; $S_{a}\left(=1-S_{L}\right)$ is the degree of air saturation in the soil; $S_{L}\left(=\theta_{L} / \varepsilon\right)$ is the degree of saturation in the soil; $H_{c}$ is Henry's constant; $D_{e}\left(\mathrm{~m}^{2} \mathrm{~s}^{-1}\right)$ is the molecular diffusivity of water vapor in soil; $K_{g}\left(\mathrm{~m}^{2}\right)$ is the intrinsic air permeability; $\mu_{a}\left(\mathrm{~kg} \mathrm{~m}^{-2} \mathrm{~s}^{-1}\right)$ is the air viscosity; $\theta_{a}\left(=\theta_{\mathrm{V}}\right)$ is the volumetric fraction of dry air in the soil; and $D_{V g}\left(\mathrm{~m}^{2} \mathrm{~s}^{-1}\right)$ is the gas phase longitudinal dispersion coefficient.

\section{A.2 Snowpack module UEB}

\section{A.2.1 Mass balance equation}

The increase or decrease of snow water equivalence with time equals the difference of income and outgoing water flux: 


$$
\frac{d S W E}{d t}=P_{r}+P_{S}-M_{r}-E
$$

490 where $S W E(\mathrm{~m})$ is the snow water equivalent; $P_{r}(\mathrm{~m} / \mathrm{s})$ is the rainfall rate; $P_{S}(\mathrm{~m} / \mathrm{s})$ is the snowfall rate; $M_{r}$ $(\mathrm{m} / \mathrm{s})$ is the meltwater outflow from the snowpack; and $E$ is the sublimation from the snowpack.

\section{A.2.2 Energy balance equation}

The energy balance of snowpack can be expressed as:

$$
\frac{d U}{d t}=Q_{s n}+Q_{l i}+Q_{p}+Q_{g}-Q_{l e}+Q_{h}+Q_{e}-Q_{m}
$$

where $Q_{s n}\left(\mathrm{~W} / \mathrm{m}^{2}\right)$ is the net shortwave radiation; $Q_{l i}\left(\mathrm{~W} / \mathrm{m}^{2}\right)$ is the incoming longwave radiation; $Q_{p}\left(\mathrm{~W} / \mathrm{m}^{2}\right)$ is the advected heat from precipitation; $Q_{g}\left(\mathrm{~W} / \mathrm{m}^{2}\right)$ is the ground heat flux; $Q_{l e}\left(\mathrm{~W} / \mathrm{m}^{2}\right)$ is the outgoing longwave radiation; $Q_{h}\left(\mathrm{~W} / \mathrm{m}^{2}\right)$ is the sensible heat flux; $Q_{e}\left(\mathrm{~W} / \mathrm{m}^{2}\right)$ is the latent heat flux due to sublimation/condensation; and $Q_{m}\left(\mathrm{~W} / \mathrm{m}^{2}\right)$ is the advected heat removed by meltwater.

Equations (8) and (9) form a coupled set of first order, nonlinear ordinary differential equations. Euler predictor-corrector approach was employed in UEB model to solve the initial value problems of these equations (Tarboton and Luce, 1996).

\section{A.3 Albedo calculation}

\section{A.3.1 Ground albedo}

Instead of the constant bare soil albedo in the original UEB model, the bare soil albedo is expressed as a decreasing linear function of soil moisture in STEMMUS-UEB.

$$
\begin{aligned}
& \alpha_{g, v}=\alpha_{\text {sat }}+\min \left\{\alpha_{\text {sat }}, \max [(0.11-0.4 \theta), 0]\right\} \\
& \alpha_{g, i r}=2 \alpha_{g, v}
\end{aligned}
$$

where $\alpha_{g, v}$ and $\alpha_{g, \text { ir }}$ are the bare soil/ground albedo for the visible and infrared band, respectively. $\alpha_{\text {sat }}$ is the saturated soil albedo, depending on local soil color. $\theta$ is the surface volumetric soil moisture.

\section{A.3.2 Vegetation albedo}

The calculation of vegetation albedo is developed to capture the essential features of a two-stream approximation model using asymptotic equation. It approaches the underlying surface albedo $\alpha_{g, \lambda}$ or the thick canopy albedo $\alpha_{c, \lambda}$ when the $L_{S A I}$ is close to zero or infinity.

$$
\begin{aligned}
& \alpha_{V e g, b, \lambda}=\alpha_{c, \lambda}\left[1-\exp \left(-\frac{\omega_{\lambda} \beta L_{S A I}}{\mu \alpha_{c, \lambda}}\right)\right]+\alpha_{g, \lambda} \exp \left[-\left(1+\frac{0.5}{\mu}\right) L_{S A I}\right] \\
& \alpha_{V e g, d, \lambda}=\alpha_{c, \lambda}\left[1-\exp \left(-\frac{2 \omega_{\lambda} \beta L_{S A I}}{\alpha_{c, \lambda}}\right)\right]+\alpha_{g, \lambda} \exp \left[-2 L_{S A I}\right]
\end{aligned}
$$

where subscripts $V e g, b, d, c, g$ and $\lambda$ represent vegetation, direct beam, diffuse radiation, thick canopy, ground, and spectrum bands of either visible or infrared bands. $\mu$ is the cosine of solar zenith angle; $\omega_{\lambda}$ is the single scattering albedo, 0.15 for visible and 0.85 for infrared band, respectively; $\beta$ is assigned as 0.5 ; $L_{S A I}$ is the sum of leaf area index LAI and stem area index SAI; $\alpha_{c, \lambda}$ is the thick canopy albedo dependent on vegetation types. 
The bulk snow-free surface albedo, averaged between bare ground albedo and vegetation albedo, then is written as:

$$
\alpha_{\eta, \lambda}=\alpha_{V e g, \lambda} f_{V e g}+\alpha_{g, \lambda}\left(1-f_{V e g}\right)
$$

where $\alpha_{\eta, \lambda}$ is the averaged bulk snow-free surface albedo; $f_{V e g}$ is the fraction of vegetation cover.

\section{A.3.3 Snow albedo}

520 According to Dickinson et al. (1993), snow albedo can be expressed as a function of snow surface age and solar illumination angle. The snow surface age, which is dependent on snow surface temperature and snowfall, is updated with each time step in UEB. Visible and near infrared bands are separately treated when calculating reflectance, which are further averaged as the albedo with modifications of illumination angle and snow age. The reflectance in the visible and near infrared bands can be written as:

$$
\begin{aligned}
& \alpha_{v d}=\left(1-C_{v} S_{a g e}\right) \alpha_{v o} \\
& \alpha_{i r d}=\left(1-C_{\text {ir }} S_{\text {age }}\right) \alpha_{\text {iro }}
\end{aligned}
$$

525 where $\alpha_{v d}$ and $\alpha_{i r d}$ represent diffuse reflectance in the visible and near infrared bands, respectively. $C_{v}$ (= $0.2)$ and $C_{i r}(=0.5)$ are parameters that quantify the sensitivity of the visible and infrared band albedo to snow surface aging (grain size growth), $\alpha_{v o}(=0.85)$ and $\alpha_{i r o}(=0.65)$ are fresh snow reflectance in visible and infrared bands, respectively. $S_{a g e}$ is a function to account for aging of the snow surface, and is given by:

$$
S_{a g e}=\frac{\tau}{1+\tau}
$$

530 where $\tau$ is the non-dimensional snow surface age that is incremented at each time step by the quantity designed to emulate the effect of the growth of surface grain sizes.

$$
\Delta \tau=\frac{r_{1}+r_{2}+r_{3}}{\tau_{o}} \Delta t
$$

where $\Delta t$ is the time step in seconds with $\tau_{o}=10^{6} \mathrm{~s}$. $\mathrm{r}_{1}$ is the parameter to represent the effect of grain growth due to vapor diffusion, and is dependent on snow surface temperature:

$$
r_{1}=\exp \left[5000\left(\frac{1}{273.16}-\frac{1}{T_{S}}\right)\right]
$$

$r_{2}$ describes the additional effect near and at the freezing point due to melt and refreeze:

$$
r_{2}=\min \left(r_{1}^{10}, 1\right)
$$

$535 r_{3}=0.03$ (0.01 in Antarctica) represents the effect of dirt and soot.

The reflectance of radiation with illumination angle (measured relative to the surface normal) is computed as:

$$
\alpha_{v}=\alpha_{v d}+0.4 f(\varphi)\left(1-\alpha_{v d}\right)
$$


https://doi.org/10.5194/gmd-2020-416

Preprint. Discussion started: 17 February 2021

(C) Author(s) 2021. CC BY 4.0 License.

$$
\alpha_{i r}=\alpha_{i r d}+0.4 f(\varphi)\left(1-\alpha_{i r d}\right)
$$

where $f(\varphi)=\left\{\begin{array}{cc}\frac{1}{b}\left[\frac{b+1}{1+2 b \cos (\varphi)}-1\right], & \text { for } \cos (\varphi)<0.5 \\ 0, & \text { otherwise }\end{array}\right.$

where $b$ is a parameter set at 2 as Dickinson et al. (1993).

540 When the snowpack is shallow (depth $\mathrm{z}<\mathrm{h}=0.01 \mathrm{~m}$ ), the albedo is calculated by interpolating between the snow albedo and bare ground albedo with the exponential term approximating the exponential extinction of radiation penetration of snow.

$$
A_{v / i r}=r \alpha_{g, v / i r}+(1-r) \alpha_{v / i r}
$$

where $r=\left(1-\frac{z}{h}\right) e^{-z / 2 h}$. 
Notation

\begin{tabular}{|c|c|c|c|}
\hline Symbol & Parameter & Unit & Value \\
\hline \multicolumn{4}{|c|}{ Main inputs } \\
\hline \multicolumn{4}{|c|}{ Soil model component (STEMMUS-FT) } \\
\hline$a$ & Fitted parameter for soil surface resistance & - & 0.3565 \\
\hline$b(z)$ & Normalized water uptake distribution & $\mathrm{m}^{-1}$ & \\
\hline$C_{a}$ & Specific heat capacity of dry air & $\mathrm{J} \mathrm{kg}^{-1{ }^{\circ} \mathrm{C}-1}$ & 1.005 \\
\hline$C_{\text {app }}$ & Apparent heat capacity & $\mathrm{J} \mathrm{kg}^{-1{ }^{\circ} \mathrm{C}-1}$ & \\
\hline$C_{i}$ & Specific heat capacity of ice & $\mathrm{J} \mathrm{kg}^{-1{ }^{\circ} \mathrm{C}-1}$ & 2.0455 \\
\hline$C_{L}$ & Specific heat capacity of liquid & $\mathrm{J} \mathrm{kg}^{-1{ }^{\circ} \mathrm{C}-1}$ & 4.186 \\
\hline$C_{s}$ & Specific heat capacity of soil solids & $\mathrm{J} \mathrm{kg}^{-1{ }^{\circ} \mathrm{C}-1}$ & \\
\hline$C_{\text {soil }}$ & Heat capacity of the bulk soil & $\mathrm{J} \mathrm{kg}^{-1{ }^{\circ} \mathrm{C}-1}$ & \\
\hline$C_{V}$ & Specific heat capacity of water vapor & $\mathrm{J} \mathrm{kg}^{-1{ }^{\circ} \mathrm{C}-1}$ & 1.87 \\
\hline$c_{p}$ & Specific heat capacity of air & $\mathrm{J} \mathrm{kg}^{-1} \mathrm{~K}^{-1}$ & \\
\hline$D_{e}$ & Molecular diffusivity of water vapor in soil & $\mathrm{m}^{2} \mathrm{~s}^{-1}$ & \\
\hline$D_{T D}$ & $\begin{array}{l}\text { Transport coefficient for adsorbed liquid flow due to } \\
\text { temperature gradient }\end{array}$ & $\mathrm{kg} \mathrm{m}^{-1} \mathrm{~s}^{-1}{ }^{\circ} \mathrm{C}^{-1}$ & \\
\hline$D_{V a}$ & Advective vapor transfer coefficient & $\mathrm{s}$ & \\
\hline$D_{V g}$ & Gas phase longitudinal dispersion coefficient & $\mathrm{m}^{2} \mathrm{~s}^{-1}$ & \\
\hline$D_{V h}$ & Isothermal vapor conductivity & $\mathrm{kg} \mathrm{m}^{-2} \mathrm{~s}^{-1}$ & \\
\hline$D_{V T}$ & Thermal vapor diffusion coefficient & $\mathrm{kg} \mathrm{m}^{-1} \mathrm{~s}^{-1}{ }^{\circ} \mathrm{C}^{-1}$ & \\
\hline$H_{c}$ & Henry's constant & - & 0.02 \\
\hline K & Hydraulic conductivity & $\mathrm{m} \mathrm{s}^{-1}$ & \\
\hline$K_{g}$ & Intrinsic air permeability & $\mathrm{m}^{2}$ & \\
\hline$K_{\text {Lh }}$ & Isothermal hydraulic conductivities & $\mathrm{m} \mathrm{s}^{-1}$ & \\
\hline$K_{L T}$ & Thermal hydraulic conductivities & $\mathrm{m}^{2} \mathrm{~s}^{-{ }^{\circ} \mathrm{C}-1}$ & \\
\hline$K_{\mathrm{s}}$ & Soil saturated hydraulic conductivity & $\mathrm{m} \mathrm{s}^{-1}$ & \\
\hline$L_{0}$ & $\begin{array}{l}\text { Latent heat of vaporization of water at the reference } \\
\text { temperature }\end{array}$ & $\mathrm{J} \mathrm{kg}^{-1}$ & \\
\hline$L A I_{\text {eff }}$ & Effective leaf area index & - & \\
\hline$L_{f}$ & Latent heat of fusion & $\mathrm{J} \mathrm{kg}^{-1}$ & $3.34 \mathrm{E}+05$ \\
\hline$n$ & Van Genuchten fitting parameters & - & \\
\hline$r_{a}^{c}$ & Aerodynamic resistance for canopy surface & $\mathrm{s} \mathrm{m}^{-1}$ & \\
\hline$r_{a}^{S}$ & Aerodynamic resistance for bare soil & $\mathrm{s} \mathrm{m}^{-1}$ & \\
\hline$r_{c, \min }$ & Minimum canopy surface resistance & $\mathrm{s} \mathrm{m}^{-1}$ & \\
\hline$r_{l, \min }$ & Minimum leaf stomatal resistance & $\mathrm{s} \mathrm{m}^{-1}$ & \\
\hline$r_{s}$ & Soil surface resistance & $\mathrm{s} \mathrm{m}^{-1}$ & \\
\hline$r_{s l}$ & Resistance to molecular diffusion of the water surface & $\mathrm{s} \mathrm{m}^{-1}$ & 10 \\
\hline$R_{n}$ & Net radiation & $\mathrm{MJ} \mathrm{m}^{-2}$ day $^{-1}$ & \\
\hline$R_{n}^{c}$ & Net radiation at the canopy surface & $\mathrm{MJ} \mathrm{m}^{-2}$ day $^{-1}$ & \\
\hline$R_{n}^{s}$ & Net radiation at the soil surface & $\mathrm{MJ} \mathrm{m}^{-2}$ day $^{-1}$ & \\
\hline$S_{a}$ & Degree of saturation of the soil air & - & $=1-S_{L}$ \\
\hline$S_{L}$ & Degree of water saturation in the soil & - & $=\theta_{L} / \varepsilon$ \\
\hline$S_{p}$ & Potential water uptake rate & $\mathrm{s}^{-1}$ & \\
\hline
\end{tabular}


$\mathrm{m} \mathrm{s}^{-1}$

${ }^{\circ} \mathrm{C}$

$\mathrm{J} \mathrm{kg}^{-1}$

$\mathrm{m}$

$\mathrm{m}^{-1}$

$\mathrm{W} \mathrm{m}^{-1}{ }^{\circ} \mathrm{C}-1$

$\mathrm{m}^{3} \mathrm{~m}^{-3}$

$\mathrm{m}^{3} \mathrm{~m}^{-3}$

$\mathrm{m}^{3} \mathrm{~m}^{-3}$

$\mathrm{m}^{3} \mathrm{~m}^{-3}$

$\mathrm{m}^{3} \mathrm{~m}^{-3}$

$\mathrm{kg} \mathrm{m}^{-3}$

$\mathrm{kg} \mathrm{m}^{-3}$

$\mathrm{kg} \mathrm{m}^{-3}$

$\mathrm{kg} \mathrm{m}^{-3}$

$\mathrm{kg} \mathrm{m}^{-3}$

$\mathrm{kg} \mathrm{m}^{-3}$

$\mathrm{kg} \mathrm{m}^{-2} \mathrm{~s}^{-2}$

$\mathrm{kg} \mathrm{m}^{-2} \mathrm{~s}^{-1}$
20

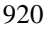

1000

$\rho$

$\rho_{V}$

Density of water vapor

Specific weight of water

Air viscosity

$\mu_{a}$ Snow model component (UEB)

\begin{tabular}{|c|c|c|c|}
\hline$T_{\mathrm{r}}$ & Air temperature above which precipitation is all rain & ${ }^{\circ} \mathrm{C}$ & 3.5 \\
\hline$T_{\mathrm{sn}}$ & Air temperature below which precipitation is all snow & ${ }^{\circ} \mathrm{C}$ & 0 \\
\hline$\varepsilon_{\mathrm{sn}}$ & Emissivity of snow & - & 0.99 \\
\hline$C_{\mathrm{g}}$ & Ground heat capacity & $\mathrm{J} \mathrm{kg}^{-1{ }^{\circ} \mathrm{C}-1}$ & 2.09 \\
\hline$z_{0}$ & Snow surface aerodynamic roughness & $\mathrm{m}$ & 0.001 \\
\hline$L_{\mathrm{c}}$ & Liquid holding capacity of snow & - & 0.05 \\
\hline$K_{\mathrm{sn}}$ & Snow saturated hydraulic conductivity & $\mathrm{m} \mathrm{h}^{-1}$ & 160 \\
\hline$\alpha_{\mathrm{vo}}$ & Visual new snow albedo & - & 0.95 \\
\hline$\alpha_{\text {iro }}$ & Near-infrared new snow albedo & - & 0.65 \\
\hline$\alpha$ bg & Bare ground albedo & - & Eqs. A10 - A14 \\
\hline$D_{\mathrm{e}}$ & Thermally active depth of soil & $\mathrm{m}$ & 0.4 \\
\hline$\lambda_{\mathrm{sn}}$ & Snow surface thermal conductivity & $\mathrm{m} \mathrm{h}^{-1}$ & 0.02 \\
\hline$\rho_{\mathrm{sn}}$ & Snow density & $\mathrm{kg} \mathrm{m}^{-3}$ & 450 \\
\hline$A_{\text {ed }}$ & Albedo extinction depth & $\mathrm{m}$ & 0.0001 \\
\hline$F_{\mathrm{c}}$ & Forest cover fraction & - & 0 \\
\hline$D_{\mathrm{f}}$ & Drift factor & - & 1 \\
\hline$\rho_{\mathrm{s}}$ & Soil density & $\mathrm{kg} \mathrm{m}^{-3}$ & 1700 \\
\hline
\end{tabular}

Main outputs

Soil model component (STEMMUS-FT)

$\psi \quad$ Soil water potential

m 


\begin{tabular}{|c|c|c|}
\hline$P_{g}$ & Mixed pore-air pressure & $\mathrm{Pa}$ \\
\hline$T$ & Soil temperature & ${ }^{\circ} \mathrm{C}$ \\
\hline$\theta$ & Volumetric water content & $\mathrm{m}^{3} \mathrm{~m}^{-3}$ \\
\hline$\theta_{i}$ & Soil ice volumetric water content & $\mathrm{m}^{3} \mathrm{~m}^{-3}$ \\
\hline$\theta_{L}$ & Soil liquid volumetric water content & $\mathrm{m}^{3} \mathrm{~m}^{-3}$ \\
\hline$\theta_{V}$ & Soil vapor volumetric water content & $\mathrm{m}^{3} \mathrm{~m}^{-3}$ \\
\hline$\theta_{a}$ & Volumetric fraction of dry air in the soil & $\mathrm{m}^{3} \mathrm{~m}^{-3}$ \\
\hline$q$ & Water flux & $\mathrm{kg} \mathrm{m}^{-2} \mathrm{~s}^{-1}$ \\
\hline$q_{a}$ & Dry air flux & $\mathrm{kg} \mathrm{m}^{-2} \mathrm{~s}^{-1}$ \\
\hline$q_{L}$ & Soil liquid water fluxes (positive upwards) & $\mathrm{kg} \mathrm{m}^{-2} \mathrm{~s}^{-1}$ \\
\hline$q_{L a}$ & Liquid water flux driven by the gradient of air pressure & $\mathrm{kg} \mathrm{m}^{-2} \mathrm{~s}^{-1}$ \\
\hline$q_{L h}$ & Liquid water flux driven by the gradient of matric potential & $\mathrm{kg} \mathrm{m}^{-2} \mathrm{~s}^{-1}$ \\
\hline$q_{L T}$ & Liquid water flux driven by the gradient of temperature & $\mathrm{kg} \mathrm{m}^{-2} \mathrm{~s}^{-1}$ \\
\hline$q_{V}$ & Soil water vapor fluxes (positive upwards) & $\mathrm{kg} \mathrm{m}^{-2} \mathrm{~s}^{-1}$ \\
\hline$q_{V a}$ & Water vapor flux driven by the gradient of air pressure & $\mathrm{kg} \mathrm{m}^{-2} \mathrm{~s}^{-1}$ \\
\hline$q_{V h}$ & Water vapor flux driven by the gradient of matric potential & $\mathrm{kg} \mathrm{m}^{-2} \mathrm{~s}^{-1}$ \\
\hline$q_{V T}$ & Water vapor flux driven by the gradient of temperature & $\mathrm{kg} \mathrm{m}^{-2} \mathrm{~s}^{-1}$ \\
\hline$S$ & Sink term for transpiration & $\mathrm{s}^{-1}$ \\
\hline$S_{h}$ & Latent heat flux density & $\mathrm{W} \mathrm{m}^{-3}$ \\
\hline \multicolumn{3}{|c|}{ Snow model component (UEB) } \\
\hline$P_{\mathrm{r}}$ & Precipitation in the form of rain & $\mathrm{m} \mathrm{s}^{-1}$ \\
\hline$P_{\mathrm{s}}$ & Precipitation in the form of snow & $\mathrm{m} \mathrm{s}^{-1}$ \\
\hline SWE & Snow water equivalent & $\mathrm{m}$ \\
\hline$Q_{\mathrm{h}}$ & Surface Sensible Heat Flux & $\mathrm{W} \mathrm{m}^{-2}$ \\
\hline$Q_{\mathrm{e}}$ & Surface Latent Heat Flux & $\mathrm{W} \mathrm{m}^{-2}$ \\
\hline E & Surface Sublimation & $\mathrm{m} \mathrm{s}^{-1}$ \\
\hline$T_{\text {surf }}$ & Snow Surface Temperature & ${ }^{\circ} \mathrm{C}$ \\
\hline$U$ & Energy Content & \\
\hline$M_{\mathrm{r}}$ & Melt outflow rate & $\mathrm{m} \mathrm{s}^{-1}$ \\
\hline$A_{\mathrm{v} / \mathrm{ir}}$ & Surface Albedo & - \\
\hline$Q_{\mathrm{m}}$ & Heat advected by melt outflow & $\mathrm{W} \mathrm{m}^{-2}$ \\
\hline$Q_{\text {sn }}$ & Net shortwave radiation & $\mathrm{W} \mathrm{m}^{-2}$ \\
\hline$Q_{\mathrm{li}}$ & Net longwave radiation & $\mathrm{W} \mathrm{m}^{-2}$ \\
\hline$\tau$ & No-dimensional snow age & - \\
\hline
\end{tabular}




\section{Reference}

Barlett, P. A., MacKay, M. D., and Verseghy, D. L.: Modified snow algorithms in the Canadian Land Surface Scheme: Model runs and sensitivity analysis at three boreal forest stands, Atmosphere - Ocean, 44, 207-222, https://doi.org/10.3137/ao.440301, 2006.

550 Barrere, M., Domine, F., Decharme, B., Morin, S., Vionnet, V., and Lafaysse, M.: Evaluating the performance of coupled snow-soil models in SURFEXv8 to simulate the permafrost thermal regime at a high Arctic site, Geoscientific Model Development, 10, 3461-3479, https://doi.org/10.5194/gmd-10-3461-2017, 2017.

Best, M. J.: The Joint UK Land Environment Simulator (JULES), model description - Part 1: Energy and 555 water fluxes, Geosci Model Dev, 4, 677-699, 2011.

Boone, A., Samuelsson, P., Gollvik, S., Napoly, A., Jarlan, L., Brun, E., and Decharme, B.: The interactions between soil-biosphere-atmosphere land surface model with a multi-energy balance (ISBA-MEB) option in SURFEXv8 - Part 1: Model description, Geosci Model Dev, 10, 843-872, https://doi.org/10.5194/gmd-10843-2017, 2017.

560 Boone, A. A., and Etchevers, P.: An intercomparison of three snow schemes of varying complexity coupled to the same land surface model: Local-scale evaluation at an alpine site, J Hydrometeorol, 2, 374-394, https://doi.org/10.1175/1525-7541(2001)002<0374:AIOTSS>2.0.CO;2, 2001.

Clark, M. P., Nijssen, B., Lundquist, J. D., Kavetski, D., Rupp, D. E., Woods, R. A., Freer, J. E., Gutmann, E. D., Wood, A. W., Brekke, L. D., Arnold, J. R., Gochis, D. J., and Rasmussen, R. M.: A unified approach

565 for process-based hydrologic modeling: 1. Modeling concept, Water Resour Res, 51, 2498-2514, https://doi.org/10.1002/2015wr017198, 2015.

Cuntz, M., and Haverd, V.: Physically Accurate Soil Freeze-Thaw Processes in a Global Land Surface Scheme, Journal of Advances in Modeling Earth Systems, 10, 54-77, https://doi.org/10.1002/2017ms001100, 2018.

570 De Vries, D. A.: Simultaneous transfer of heat and moisture in porous media, Eos, Transactions American Geophysical Union, 39, 909-916, https://doi.org/10.1029/TR039i005p00909, 1958.

Decharme, B., Brun, E., Boone, A., Delire, C., Le Moigne, P., and Morin, S.: Impacts of snow and organic soils parameterization on northern Eurasian soil temperature profiles simulated by the ISBA land surface model, Cryosphere, 10, 853-877, https://doi.org/10.5194/tc-10-853-2016, 2016.

575 Dente, L., Vekerdy, Z., Wen, J., and Su, Z.: Maqu network for validation of satellite-derived soil moisture products, Int J Appl Earth Obs Geoinf, 17, 55-65, https://doi.org/10.1016/j.jag.2011.11.004, 2012.

Dickinson, R. E., Henderson-Sellers, A., and Kennedy, P. J.: Biosphere-atmosphere Transfer Scheme (BATS) Version 1e as Coupled to the NCAR Community Climate Model (No. NCAR/TN-387+STR), University Corporation for Atmospheric Research, 1993.

580 Ding, B., Yang, K., Yang, W., He, X., Chen, Y., Lazhu, Guo, X., Wang, L., Wu, H., and Yao, T.: Development of a Water and Enthalpy Budget-based Glacier mass balance Model (WEB-GM) and its preliminary validation, Water Resour Res, 53, 3146-3178, https://doi.org/10.1002/2016WR018865, 2017. Domine, F., Picard, G., Morin, S., Barrere, M., Madore, J.-B., and Langlois, A.: Major Issues in Simulating Some Arctic Snowpack Properties Using Current Detailed Snow Physics Models: Consequences for the

585 Thermal Regime and Water Budget of Permafrost, Journal of Advances in Modeling Earth Systems, 11, 3444, https://doi.org/10.1029/2018ms001445, 2019.

Douville, H., Royer, J. F., and Mahfouf, J. F.: A new snow parameterization for the Météo-France climate model, Clim Dyn, 12, 21-35, https://doi.org/10.1007/BF00208760, 1995.

Dutra, E., Balsamo, G., Viterbo, P., Miranda, P. M. A., Beljaars, A., Schar, C., and Elder, K.: An improved

590 snow scheme for the ECMWF land surface model: Description and offline validation, J Hydrometeorol, 11, 899-916, https://doi.org/10.1175/2010JHM1249.1, 2010.

Dutra, E., Viterbo, P., Miranda, P. M. A., and Balsamo, G.: Complexity of snow schemes in a climate model and its impact on surface energy and hydrology, J Hydrometeorol, 13, 521-538, https://doi.org/10.1175/JHMD-11-072.1, 2012.

595 Ekici, A., Beer, C., Hagemann, S., Boike, J., Langer, M., and Hauck, C.: Simulating high-latitude permafrost regions by the JSBACH terrestrial ecosystem model, Geoscientific Model Development, 7, 631-647, https://doi.org/10.5194/gmd-7-631-2014, 2014. 
Etchevers, P., Martin, E., Brown, R., Fierz, C., Lejeune, Y., Bazile, E., Boone, A., Dai, Y.-J., Essery, R., Fernandez, A., Gusev, Y., Jordan, R., Koren, V., Kowalczyk, E., Nasonova, N. O., Pyles, R. D., Schlosser, 600 A., Shmakin, A. B., Smirnova, T. G., Strasser, U., Verseghy, D., Yamazaki, T., and Yang, Z.-L.: Validation of the energy budget of an alpine snowpack simulated by several snow models (SnowMIP project), Ann Glaciol, 38, 150-158, https://doi.org/10.3189/172756404781814825, 2004.

Flerchinger, G.: The Simultaneous Heat and Water (SHAW) Model: Technical Documentation Version 3.0, 2017.

605 Flerchinger, G. N., and Saxton, K. E.: Simultaneous heat and water model of a freezing snow-residue-soil system. I. Theory and development, Transactions of the American Society of Agricultural Engineers, 32, 565-571, 1989.

Gardiner, M. J., Ellis-Evans, J. C., Anderson, M. G., and Tranter, M.: Snowmelt modelling on Signy Island, South Orkney Islands, Ann Glaciol, 26, 161-166, https://doi.org/10.3189/1998aog26-1-161-166, 1998.

610 Gichamo, T. Z., and Tarboton, D. G.: Ensemble Streamflow Forecasting Using an Energy Balance Snowmelt Model Coupled to a Distributed Hydrologic Model with Assimilation of Snow and Streamflow Observations, Water Resour Res, 55, 10813-10838, https://doi.org/10.1029/2019wr025472, 2019.

Günther, D., Marke, T., Essery, R., and Strasser, U.: Uncertainties in Snowpack Simulations_-Assessing the Impact of Model Structure, Parameter Choice, and Forcing Data Error on Point-Scale Energy Balance Snow

615 Model Performance, Water Resour Res, 55, 2779-2800, https://doi.org/10.1029/2018wr023403, 2019.

Gusev, Y. M., and Nasonova, O. N.: The simulation of heat and water exchange in the boreal spruce forest by the land-surf ace model SWAP, J Hydrol, 280, 162-191, https://doi.org/10.1016/S0022-1694(03)00221X, 2003.

Hagedorn, B., Sletten, R. S., and Hallet, B.: Sublimation and ice condensation in hyperarid soils: Modeling

620 results using field data from Victoria Valley, Antarctica, Journal of Geophysical Research: Earth Surface, 112, F03017, https://doi.org/10.1029/2006jf000580, 2007.

Hansson, K., Šimůnek, J., Mizoguchi, M., Lundin, L. C., and van Genuchten, M. T.: Water flow and heat transport in frozen soil: Numerical solution and freeze-thaw applications, Vadose Zone J, 3, 693-704, 2004. Harder, P., and Pomeroy, J. W.: Hydrological model uncertainty due to precipitation-phase partitioning 625 methods, Hydrol Processes, 28, 4311-4327, https://doi.org/10.1002/hyp.10214, 2014.

Hrbáček, F., Láska, K., and Engel, Z.: Effect of snow cover on the active-layer thermal regime-a case study from James Ross island, Antarctic Peninsula, Permafr Periglac Proc, 27, 307-315, 2016.

Iwata, Y., Hayashi, M., Suzuki, S., Hirota, T., and Hasegawa, S.: Effects of snow cover on soil freezing, water movement, and snowmelt infiltration: A paired plot experiment, Water Resour Res, 46, W09504,

630 https://doi.org/10.1029/2009WR008070, 2010.

Jambon-Puillet, E., Shahidzadeh, N., and Bonn, D.: Singular sublimation of ice and snow crystals, Nature Communications, 9, 4191, https://doi.org/10.1038/s41467-018-06689-x, 2018.

Jansson, P. E.: CoupModel: Model Use, Calibration, and Validation, 55, 1337, https://doi.org/10.13031/2013.42245, 2012.

635 Jordan, R.: A one-dimensional temperature model for a snow cover: Technical documentation for SNTHERM. 89, Cold Regions Research and Engineering Lab Hanover NH, 1991.

Lawrence, D. M., Fisher, R. A., Koven, C. D., Oleson, K. W., Swenson, S. C., Bonan, G., Collier, N., Ghimire, B., van Kampenhout, L., Kennedy, D., Kluzek, E., Lawrence, P. J., Li, F., Li, H., Lombardozzi, D., Riley, W. J., Sacks, W. J., Shi, M., Vertenstein, M., Wieder, W. R., Xu, C., Ali, A. A., Badger, A. M., Bisht, G.,

640 van den Broeke, M., Brunke, M. A., Burns, S. P., Buzan, J., Clark, M., Craig, A., Dahlin, K., Drewniak, B., Fisher, J. B., Flanner, M., Fox, A. M., Gentine, P., Hoffman, F., Keppel-Aleks, G., Knox, R., Kumar, S., Lenaerts, J., Leung, L. R., Lipscomb, W. H., Lu, Y., Pandey, A., Pelletier, J. D., Perket, J., Randerson, J. T., Ricciuto, D. M., Sanderson, B. M., Slater, A., Subin, Z. M., Tang, J., Thomas, R. Q., Val Martin, M., and Zeng, X.: The Community Land Model Version 5: Description of New Features, Benchmarking, and Impact 645 of Forcing Uncertainty, J Adv Model Earth Sy, 11, 4245-4287, https://doi.org/10.1029/2018MS001583, 2019. Lehning, M., Bartelt, P., Brown, B., Russi, T., Stöckli, U., and Zimmerli, M.: SNOWPACK model calculations for avalanche warning based upon a new network of weather and snow stations, Cold Regions Sci Tech, 30, 145-157, https://doi.org/10.1016/S0165-232X(99)00022-1, 1999.

Leroux, N. R., and Pomeroy, J. W.: Modelling capillary hysteresis effects on preferential flow through

650 melting and cold layered snowpacks, Adv Water Resour, 107, 250-264, https://doi.org/10.1016/j.advwatres.2017.06.024, 2017. 
Milly, P. C. D.: Moisture and heat transport in hysteretic, inhomogeneous porous media: A matric head-based formulation and a numerical model, Water Resour Res, 18, 489-498, https://doi.org/10.1029/WR018i003p00489, 1982.

655 Niu, G. Y., Yang, Z. L., Mitchell, K. E., Chen, F., Ek, M. B., Barlage, M., Kumar, A., Manning, K., Niyogi, D., Rosero, E., Tewari, M., and Xia, Y.: The community Noah land surface model with multiparameterization options (Noah-MP): 1. Model description and evaluation with local-scale measurements, Journal of Geophysical Research Atmospheres, 116, D12109, https://doi.org/10.1029/2010JD015139, 2011.

Pan, X., Helgason, W., Ireson, A., and Wheater, H.: Field-scale water balance closure in seasonally frozen 660 conditions, Hydrol Earth Syst Sci, 21, 5401-5413, https://doi.org/10.5194/hess-21-5401-2017, 2017. Pimentel, R., Herrero, J., Zeng, Y., Su, Z., and Polo, M. J.: Study of Snow Dynamics at Subgrid Scale in Semiarid Environments Combining Terrestrial Photography and Data Assimilation Techniques, J Hydrometeorol, 16, 563-578, https://doi.org/10.1175/jhm-d-14-0046.1, 2015.

Pitman, A. J., Z.-L. Yang, J. G. Cogley, and Henderson-Sellers, A.: Description of bare essentials of surface transfer for the Bureau of Meteorology Research Centre AGCM, BMRC Res. Rep., 117 pp, 1991.

Richards, L. A.: Capillary Conduction of Liquids Through Porous Mediums, Physics, 1, 318, 1931.

Rutter, N., Essery, R., Pomeroy, J., Altimir, N., Andreadis, K., Baker, I., Barr, A., Bartlett, P., Boone, A., Deng, H., Douville, H., Dutra, E., Elder, K., Ellis, C., Feng, X., Gelfan, A., Goodbody, A., Gusev, Y., Gustafsson, D., Hellström, R., Hirabayashi, Y., Hirota, T., Jonas, T., Koren, V., Kuragina, A., Lettenmaier,

670 D., Li, W.-P., Luce, C., Martin, E., Nasonova, O., Pumpanen, J., Pyles, R. D., Samuelsson, P., Sandells, M., Schädler, G., Shmakin, A., Smirnova, T. G., Stähli, M., Stöckli, R., Strasser, U., Su, H., Suzuki, K., Takata, K., Tanaka, K., Thompson, E., Vesala, T., Viterbo, P., Wiltshire, A., Xia, K., Xue, Y., and Yamazaki, T.: Evaluation of forest snow processes models (SnowMIP2), Journal of Geophysical Research: Atmospheres, 114, D06111, https://doi.org/10.1029/2008JD011063, 2009.

675 Schulz, O., and de Jong, C.: Snowmelt and sublimation: field experiments and modelling in the High Atlas Mountains of Morocco, Hydrol Earth Syst Sci, 8, 1076-1089, https://doi.org/10.5194/hess-8-1076-2004, 2004.

Shrestha, M., Wang, L., Koike, T., Xue, Y., and Hirabayashi, Y.: Improving the snow physics of WEB-DHM and its point evaluation at the SnowMIP sites, Hydrol Earth Syst Sci, 14, 2577-2594, 680 https://doi.org/10.5194/hess-14-2577-2010, 2010.

Šimůnek, J., Šejna, M., Saito, H., Sakai, M., and Van Genuchten, M.: The HYDRUS-1D Software Package for Simulating the One-Dimensional Movement of Water, Heat, and Multiple Solutes in Variably-Saturated Media, 2008.

Slater, A. G., Pitman, A. J., and Desborough, C. E.: The validation of a snow parameterization designed for

685 use in general circulation models, Int J Climatol, 18, 595-617, https://doi.org/10.1002/(sici)10970088(199805)18:6<595::aid-joc275>3.0.co;2-o, 1998.

Strasser, U., Bernhardt, M., Weber, M., Liston, G. E., and Mauser, W.: Is snow sublimation important in the alpine water balance?, The Cryosphere, 2, 53-66, https://doi.org/10.5194/tc-2-53-2008, 2008.

Su, Z., Wen, J., Dente, L., van der Velde, R., Wang, L., Ma, Y., Yang, K., and Hu, Z.: The Tibetan Plateau

690 observatory of plateau scale soil moisture and soil temperature (Tibet-Obs) for quantifying uncertainties in coarse resolution satellite and model products, Hydrol Earth Syst Sci, 15, 2303-2316, https://doi.org/10.5194/hess-15-2303-2011, 2011.

Sud, Y. C., and Mocko, D. M.: New Snow-Physics to Complement SSiB Part I: Design and Evaluation with ISLSCP Initiative I Datasets, Journal of the Meteorological Society of Japan Ser II, 77, 335-348, 695 https://doi.org/10.2151/jmsj1965.77.1B_335, 1999.

Sultana, R., Hsu, K. L., Li, J., and Sorooshian, S.: Evaluating the Utah Energy Balance (UEB) snow model in the Noah land-surface model, Hydrol Earth Syst Sci, 18, 3553-3570, https://doi.org/10.5194/hess-18-35532014, 2014.

Sun, S., Jin, J., and Xue, Y.: A simple snow-atmosphere-soil transfer model, Journal of Geophysical Research:

700 Atmospheres, 104, 19587-19597, https://doi.org/10.1029/1999jd900305, 1999.

Tarboton, D. G., and Luce, C. H.: Utah Energy Balance Snow Accumulation and Melt Model (UEB), Computer model technical description and users guide, Utah Water Research Laboratory and USDA Forest Service Intermountain Research Station, 1996.

Ueno, K., Tanaka, K., Tsutsui, H., and Li, M.: Snow Cover Conditions in the Tibetan Plateau Observed

705 during the Winter of 2003/2004, Arctic, Antarctic, and Alpine Research, 39, 152-164, https://doi.org/10.1657/1523-0430(2007)39[152:SCCITT]2.0.CO;2, 2007. 
Ueno, K., Sugimoto, S., Tsutsui, H., Taniguchi, K., Hu, Z., and Wu, S.: Role of patchy snow cover on the planetary boundary layer structure during late winter observed in the central Tibetan Plateau, Journal of the Meteorological Society of Japan Ser II, 90, 145-155, 2012.

710 Verseghy, D. L.: Class-A Canadian land surface scheme for GCMS. I. Soil model, Int J Climatol, 11, 111133, https://doi.org/10.1002/joc.3370110202, 1991.

Vionnet, V., Brun, E., Morin, S., Boone, A., Faroux, S., Le Moigne, P., Martin, E., and Willemet, J. M.: The detailed snowpack scheme Crocus and its implementation in SURFEX v7.2, Geosci Model Dev, 5, 773-791, https://doi.org/10.5194/gmd-5-773-2012, 2012.

715 Wang, L., Koike, T., Yang, D., and Yang, K.: Improving the hydrology of the Simple Biosphere Model 2 and its evaluation within the framework of a distributed hydrological model, Hydrol Sci J, 54, 989-1006, https://doi.org/10.1623/hysj.54.6.989, 2009.

Wang, L., Zhou, J., Qi, J., Sun, L., Yang, K., Tian, L., Lin, Y., Liu, W., Shrestha, M., Xue, Y., Koike, T., Ma, Y., Li, X., Chen, Y., Chen, D., Piao, S., and Lu, H.: Development of a land surface model with coupled

720 snow and frozen soil physics, Water Resour Res, 53, 5085-5103, https://doi.org/10.1002/2017WR020451, 2017.

Wang, T., Ottlé, C., Boone, A., Ciais, P., Brun, E., Morin, S., Krinner, G., Piao, S., and Peng, S.: Evaluation of an improved intermediate complexity snow scheme in the ORCHIDEE land surface model, Journal of Geophysical Research Atmospheres, 118, 6064-6079, https://doi.org/10.1002/jgrd.50395, 2013.

725 Wang, Y., Zeng, Y., Yu, L., Yang, P., Van de Tol, C., Cai, H., and Su, Z.: Integrated Modeling of Photosynthesis and Transfer of Energy, Mass and Momentum in the Soil-Plant-Atmosphere Continuum System, Geosci Model Dev Discuss, 2020, 1-37, https://doi.org/10.5194/gmd-2020-85, 2020.

Watson, F. G. R., Newman, W. B., Coughlan, J. C., and Garrott, R. A.: Testing a distributed snowpack simulation model against spatial observations, J Hydrol, 328, 453-466, 730 https://doi.org/10.1016/j.jhydrol.2005.12.012, 2006.

Yang, Z.-L., Dickinson, R. E., Robock, A., and Vinnikov, K. Y.: Validation of the Snow Submodel of the Biosphere-Atmosphere Transfer Scheme with Russian Snow Cover and Meteorological Observational Data, J Clim, 10, 353-373, https://doi.org/10.1175/1520-0442(1997)010<0353:votsso>2.0.co;2, 1997.

Yi, Y., Kimball, J. S., Rawlins, M. A., Moghaddam, M., and Euskirchen, E. S.: The role of snow cover

735 affecting boreal-arctic soil freeze-thaw and carbon dynamics, Biogeosciences, 12, 5811-5829, https://doi.org/10.5194/bg-12-5811-2015, 2015.

You, Y., Meng, H., Dong, J., and Rudlosky, S.: Time-Lag Correlation Between Passive Microwave Measurements and Surface Precipitation and Its Impact on Precipitation Retrieval Evaluation, Geophys Res Lett, 46, 8415-8423, https://doi.org/10.1029/2019gl083426, 2019.

740 Yu, L., Zeng, Y., Su, Z., Cai, H., and Zheng, Z.: The effect of different evapotranspiration methods on portraying soil water dynamics and ET partitioning in a semi-arid environment in Northwest China, Hydrol Earth Syst Sci, 20, 975-990, https://doi.org/10.5194/hess-20-975-2016, 2016.

Yu, L., Zeng, Y., Wen, J., and Su, Z.: Liquid-Vapor-Air Flow in the Frozen Soil, Journal of Geophysical Research: Atmospheres, 123, 7393-7415, https://doi.org/10.1029/2018jd028502, 2018.

745 Yu, L., Zeng, Y., Fatichi, S., and Su, Z.: How vadose zone mass and energy transfer physics affects the ecohydrological dynamics of a Tibetan meadow?, The Cryosphere Discuss, 2020, 1-31, https://doi.org/10.5194/tc-2020-88, 2020a.

Yu, L., Zeng, Y., and Su, Z.: STEMMUS-UEB v1.0: Integrated Modeling of Snowpack and Soil Mass and Energy Transfer with Three Levels of Soil Physical Process Complexities, Zenodo, 750 http://doi.org/10.5281/zenodo.3975846, 2020b.

Yu, L., Zeng, Y., and Su, Z.: Understanding the mass, momentum, and energy transfer in the frozen soil with three levels of model complexities, Hydrol Earth Syst Sci, 24, 4813-4830, https://doi.org/10.5194/hess-244813-2020, 2020c.

Zeng, Y., Su, Z., Wan, L., and Wen, J.: Numerical analysis of air-water-heat flow in unsaturated soil: Is it

755 necessary to consider airflow in land surface models?, Journal of Geophysical Research: Atmospheres, 116, D20107, https://doi.org/10.1029/2011JD015835, 2011a.

Zeng, Y., Su, Z., Wan, L., and Wen, J.: A simulation analysis of the advective effect on evaporation using a two-phase heat and mass flow model, Water Resour Res, 47, W10529, https://doi.org/10.1029/2011WR010701, 2011b.

760 Zeng, Y., Su, Z., van der Velde, R., Wang, L., Xu, K., Wang, X., and Wen, J.: Blending Satellite Observed, Model Simulated, and in Situ Measured Soil Moisture over Tibetan Plateau, Remote Sensing, 8, 268, 2016. 
Zeng, Y. J., and Su, Z. B.: STEMMUS : Simultaneous Transfer of Engery, Mass and Momentum in Unsaturated Soil, ISBN: 978-90-6164-351-7, University of Twente, Faculty of Geo-Information and Earth Observation (ITC), Enschede, 2013.

765 Zhang, T.: Influence of the seasonal snow cover on the ground thermal regime: An overview, Rev Geophys, 43, RG4002, https://doi.org/10.1029/2004rg000157, 2005.

Zhao, H., Zeng, Y., Lv, S., and Su, Z.: Analysis of Soil Hydraulic and Thermal Properties for Land Surface Modelling over the Tibetan Plateau, Earth Syst Sci Data Discuss, 2018, 1-40, https://doi.org/10.5194/essd2017-122, 2018.

770 Zheng, D., Van der Velde, R., Su, Z., Wang, X., Wen, J., Booij, M. J., Hoekstra, A. Y., and Chen, Y.: Augmentations to the Noah Model Physics for Application to the Yellow River Source Area. Part I: Soil Water Flow, J Hydrometeorol, 16, 2659-2676, https://doi.org/10.1175/JHM-D-14-0198.1, 2015. 
https://doi.org/10.5194/gmd-2020-416

Preprint. Discussion started: 17 February 2021

(C) Author(s) 2021. CC BY 4.0 License.

(c) (i)

775 Tables and Figures 
Table 1. Brief overview of current soil-snow modelling efforts.

\begin{tabular}{|c|c|c|c|c|c|c|c|c|c|c|c|c|}
\hline \multirow[b]{2}{*}{ Model } & \multicolumn{5}{|l|}{ Soil } & \multicolumn{6}{|l|}{ Snow } & \multirow[b]{2}{*}{$\begin{array}{l}\text { Relevant } \\
\text { reference }\end{array}$} \\
\hline & $\begin{array}{l}\text { Water } \\
\text { balan } \\
\text { ce }\end{array}$ & $\begin{array}{l}\text { Energy } \\
\text { balanc } \\
\text { e }\end{array}$ & $\begin{array}{l}\text { Air } \\
\text { bala } \\
\text { nce }\end{array}$ & $\begin{array}{l}\text { Water- } \\
\text { heat } \\
\text { coupled }\end{array}$ & $\begin{array}{l}\text { Others } \\
\text { (vapor, } \\
\text { freeze-thaw, } \\
\text { convective } \\
\text { heat) }\end{array}$ & $\begin{array}{l}\text { Snow } \\
\text { layer }\end{array}$ & $\begin{array}{l}\text { Snow } \\
\text { energy } \\
\text { budget }\end{array}$ & $\begin{array}{l}\text { Water } \\
\text { flow }\end{array}$ & Snow albedo & Snow density & $\begin{array}{l}\text { Other processes (snow } \\
\text { compaction, wind, and } \\
\text { vegetation effect) }\end{array}$ & \\
\hline CABLE-SLI & $\begin{array}{l}\text { Richa } \\
\text { rds }\end{array}$ & $\begin{array}{l}\text { HT_co } \\
\text { nd, } \\
\text { Advc }\end{array}$ & No & Yes & $\begin{array}{l}\text { Vapor; } \\
\text { HT_convect } \\
\text { (liquid) }\end{array}$ & $\begin{array}{l}\text { Multila } \\
\text { yer }\end{array}$ & $\begin{array}{l}\text { HT_co } \\
\text { nd, } \\
\text { Advc }\end{array}$ & $\begin{array}{l}\text { Mass } \\
\text { conserva } \\
\text { tion } \\
\text { Snowfall }\end{array}$ & $\begin{array}{l}\text { Albedo_SN } \\
\text { W_1A }\end{array}$ & $\begin{array}{l}\text { Density_SN } \\
\text { W_1 }\end{array}$ & $\begin{array}{l}\text { Snow compaction } \\
\text { (overburden and } \\
\text { metamorphism) }\end{array}$ & $\begin{array}{l}\text { Cuntz and } \\
\text { Haverd (2018) }\end{array}$ \\
\hline CLASS & $\begin{array}{l}\text { Richa } \\
\text { rds }\end{array}$ & $\begin{array}{l}\text { HT_co } \\
\text { nd }\end{array}$ & No & No & $\begin{array}{l}\text { No vapor; } \\
\text { LH_phas }\end{array}$ & Single & $\begin{array}{l}\text { HT_co } \\
\text { nd }\end{array}$ & $\begin{array}{l}\text {, energy } \\
\text { driven } \\
\text { snow } \\
\text { melting }\end{array}$ & $\begin{array}{l}\text { Albedo_SN } \\
\text { W_1B }\end{array}$ & $\begin{array}{l}\text { Density_SN } \\
\text { W_2A }\end{array}$ & - & $\begin{array}{l}\text { Barlett et al. } \\
\text { (2006) }\end{array}$ \\
\hline CLM5 & $\begin{array}{l}\text { Richa } \\
\text { rds }\end{array}$ & $\begin{array}{l}\text { HT_co } \\
\text { nd }\end{array}$ & No & No & $\begin{array}{l}\text { No vapor; } \\
\text { LH_phas }\end{array}$ & $\begin{array}{l}\text { Multila } \\
\text { yer up } \\
\text { to five }\end{array}$ & $\begin{array}{l}\text { HT_co } \\
\text { nd }\end{array}$ & $\begin{array}{l}\text { Mass } \\
\text { conserva } \\
\text { tion }\end{array}$ & $\begin{array}{l}\text { Albedo_SN } \\
\text { W_2 }\end{array}$ & $\begin{array}{l}\text { Density_SN } \\
\text { W_4A }\end{array}$ & $\begin{array}{l}\text { Snow compaction } \\
\text { (metamorphism, } \\
\text { overburden, melting, wind- } \\
\text { drift) }\end{array}$ & $\begin{array}{l}\text { Lawrence et al., } \\
\text { (2019) }\end{array}$ \\
\hline HTESSEL & $\begin{array}{l}\text { Richa } \\
\text { rds }\end{array}$ & $\begin{array}{l}\text { HT_co } \\
\text { nd }\end{array}$ & No & No & $\begin{array}{l}\text { No vapor; } \\
\text { LH_phas }\end{array}$ & Single & $\begin{array}{l}\text { HT_co } \\
\text { nd }\end{array}$ & $\begin{array}{l}\text { Mass } \\
\text { conserva } \\
\text { tion }\end{array}$ & $\begin{array}{l}\text { Albedo_SN } \\
\text { W_3B }\end{array}$ & $\begin{array}{l}\text { Density_SN } \\
\text { W_4B }\end{array}$ & $\begin{array}{l}\text { Snow compaction } \\
\text { (overburden and } \\
\text { metamorphism) }\end{array}$ & $\begin{array}{l}\text { Dutra et al. } \\
\text { (2010) }\end{array}$ \\
\hline $\begin{array}{l}\text { HTESSEL- } \\
\text { ML }\end{array}$ & $\begin{array}{l}\text { Richa } \\
\text { rds }\end{array}$ & $\begin{array}{l}\text { HT_co } \\
\text { nd }\end{array}$ & No & No & $\begin{array}{l}\text { No vapor; } \\
\text { LH_phas }\end{array}$ & $\begin{array}{l}\text { Multila } \\
\text { yer up } \\
\text { to } 3\end{array}$ & $\begin{array}{l}\text { HT_co } \\
\text { nd }\end{array}$ & $\begin{array}{l}\text { Mass } \\
\text { conserva } \\
\text { tion }\end{array}$ & $\begin{array}{l}\text { Albedo_SN } \\
\text { W_3B }\end{array}$ & $\begin{array}{l}\text { Density_SN } \\
\text { W_4B }\end{array}$ & $\begin{array}{l}\text { Snow compaction } \\
\text { (overburden and } \\
\text { metamorphism) }\end{array}$ & $\begin{array}{l}\text { Dutra et al. } \\
\text { (2012) }\end{array}$ \\
\hline $\begin{array}{l}\text { SURFEX- } \\
\text { ISBA-ES01 }\end{array}$ & $\begin{array}{l}\text { Richa } \\
\text { rds }\end{array}$ & $\begin{array}{l}\text { HT_co } \\
\text { nd }\end{array}$ & No & No & $\begin{array}{l}\text { No vapor; } \\
\text { LH_phas }\end{array}$ & $\begin{array}{l}\text { Multila } \\
\text { yer, } 3\end{array}$ & $\begin{array}{l}\text { HT_co } \\
\text { nd }\end{array}$ & $\begin{array}{l}\text { Mass } \\
\text { conserva } \\
\text { tion }\end{array}$ & $\begin{array}{l}\text { Albedo_SN } \\
\text { W_3A }\end{array}$ & $\begin{array}{l}\text { Density_SN } \\
\text { W_4C }\end{array}$ & $\begin{array}{l}\text { Snow compaction and } \\
\text { settling }\end{array}$ & $\begin{array}{l}\text { Boone and } \\
\text { Etchevers } \\
\text { (2001) }\end{array}$ \\
\hline $\begin{array}{l}\text { SURFEX- } \\
\text { ISBA-ES16 }\end{array}$ & $\begin{array}{l}\text { Richa } \\
\text { rds }\end{array}$ & $\begin{array}{l}\text { HT_co } \\
\text { nd }\end{array}$ & No & No & $\begin{array}{l}\text { No vapor; } \\
\text { LH_phas }\end{array}$ & $\begin{array}{l}\text { Multila } \\
\text { yer, } 12\end{array}$ & $\begin{array}{l}\text { HT_co } \\
\text { nd }\end{array}$ & $\begin{array}{l}\text { Mass } \\
\text { conserva } \\
\text { tion }\end{array}$ & $\begin{array}{l}\text { Albedo_SN } \\
\text { W_3C }\end{array}$ & $\begin{array}{l}\text { Density_SN } \\
\text { W_4D }\end{array}$ & $\begin{array}{l}\text { Snow compaction; wind- } \\
\text { induced densification }\end{array}$ & $\begin{array}{l}\text { Decharme et al. } \\
\text { (2016) }\end{array}$ \\
\hline $\begin{array}{l}\text { SURFEX- } \\
\text { ISBA-MEB }\end{array}$ & $\begin{array}{l}\text { Richa } \\
\text { rds }\end{array}$ & $\begin{array}{l}\text { HT_co } \\
\text { nd }\end{array}$ & No & No & $\begin{array}{l}\text { No vapor; } \\
\text { LH_phas }\end{array}$ & $\begin{array}{l}\text { Multila } \\
\text { yer, } 12\end{array}$ & $\begin{array}{l}\text { HT_co } \\
\text { nd }\end{array}$ & $\begin{array}{l}\text { Mass } \\
\text { conserva } \\
\text { tion }\end{array}$ & $\begin{array}{l}\text { Albedo_SN } \\
\text { W_3C }\end{array}$ & $\begin{array}{l}\text { Density_SN } \\
\text { W_4D }\end{array}$ & $\begin{array}{l}\text { Snow compaction; wind- } \\
\text { induced densification; } \\
\text { Vegetation effect } \\
\text { (interception/ unloading; } \\
\text { snow fraction); litter layer; } \\
\text { Multi-component energy } \\
\text { balance }\end{array}$ & $\begin{array}{l}\text { Boone et al. } \\
\text { (2017) }\end{array}$ \\
\hline $\begin{array}{l}\text { SURFEX- } \\
\text { Crocus }\end{array}$ & $\begin{array}{l}\text { Richa } \\
\text { rds }\end{array}$ & $\begin{array}{l}\text { HT_co } \\
\text { nd }\end{array}$ & No & No & $\begin{array}{l}\text { No vapor; } \\
\text { LH_phas }\end{array}$ & $\begin{array}{l}\text { Multila } \\
\text { yer } \\
\text { (dynam } \\
\text { ic) }\end{array}$ & $\begin{array}{l}\text { HT_co } \\
\text { nd }\end{array}$ & $\begin{array}{l}\text { Mass } \\
\text { conserva } \\
\text { tion }\end{array}$ & $\begin{array}{l}\text { Albedo_SN } \\
\text { W_3D }\end{array}$ & $\begin{array}{l}\text { Density_SN } \\
\text { W_4F }\end{array}$ & $\begin{array}{l}\text { Snow metamorphism; } \\
\text { compaction; wind drift; } \\
\text { sublimation/ hoar } \\
\text { deposition }\end{array}$ & $\begin{array}{l}\text { Vionnet et al. } \\
\text { (2012) }\end{array}$ \\
\hline JSBACH & $\begin{array}{l}\text { Richa } \\
\text { rds }\end{array}$ & $\begin{array}{l}\text { HT_co } \\
\text { nd }\end{array}$ & No & No & $\begin{array}{l}\text { No vapor; } \\
\text { LH_phas }\end{array}$ & $\begin{array}{l}\text { Multila } \\
\text { yer up } \\
\text { to } 5\end{array}$ & $\begin{array}{l}\text { HT_co } \\
\text { nd }\end{array}$ & $\begin{array}{l}\text { Mass } \\
\text { conserva } \\
\text { tion }\end{array}$ & Constant & Constant & - & $\begin{array}{l}\text { Ekici et al. } \\
\text { (2014) }\end{array}$ \\
\hline JULES & $\begin{array}{l}\text { Richa } \\
\text { rds }\end{array}$ & $\begin{array}{l}\text { HT_co } \\
\text { nd }\end{array}$ & No & No & $\begin{array}{l}\text { No vapor; } \\
\text { LH_phas }\end{array}$ & $\begin{array}{l}\text { Multila } \\
\text { yer up } \\
\text { to } 5\end{array}$ & $\begin{array}{l}\text { HT_co } \\
\text { nd }\end{array}$ & $\begin{array}{l}\text { Mass } \\
\text { conserva } \\
\text { tion }\end{array}$ & $\begin{array}{l}\text { Albedo_SN } \\
\text { W_3A }\end{array}$ & $\begin{array}{l}\text { Density_SN } \\
\text { W_4B }\end{array}$ & Snow compaction & Best (2011) \\
\hline Noah-MP & $\begin{array}{l}\text { Richa } \\
\text { rds }\end{array}$ & $\begin{array}{l}\text { HT_co } \\
\text { nd }\end{array}$ & No & No & $\begin{array}{l}\text { No vapor; } \\
\text { LH_phas }\end{array}$ & $\begin{array}{l}\text { Multila } \\
\text { yer up } \\
\text { to } 3\end{array}$ & $\begin{array}{l}\text { HT_co } \\
\text { nd }\end{array}$ & $\begin{array}{l}\text { Mass } \\
\text { conserva } \\
\text { tion }\end{array}$ & $\begin{array}{l}\text { Albedo_SN } \\
\text { W_2 }\end{array}$ & $\begin{array}{l}\text { Density_SN } \\
\text { W_2B }\end{array}$ & - & Niu et al. (2011) \\
\hline $\begin{array}{l}\text { ORCHIDEE- } \\
\text { ES }\end{array}$ & $\begin{array}{l}\text { Richa } \\
\text { rds }\end{array}$ & $\begin{array}{l}\text { HT_co } \\
\text { nd }\end{array}$ & No & No & $\begin{array}{l}\text { No vapor; } \\
\text { LH_phas }\end{array}$ & $\begin{array}{l}\text { Multila } \\
\text { yer, } 3\end{array}$ & $\begin{array}{l}\text { HT_co } \\
\text { nd }\end{array}$ & $\begin{array}{l}\text { Mass } \\
\text { conserva } \\
\text { tion }\end{array}$ & $\begin{array}{l}\text { Albedo_SN } \\
\text { W_3E }\end{array}$ & $\begin{array}{l}\text { Density_SN } \\
\text { W_4B }\end{array}$ & $\begin{array}{l}\text { Snow compaction } \\
\text { (overburden and } \\
\text { metamorphism) }\end{array}$ & $\begin{array}{l}\text { Wang et al. } \\
\text { (2013) }\end{array}$ \\
\hline $\begin{array}{l}\text { SNOWPAC } \\
\mathrm{K}\end{array}$ & $\begin{array}{l}\text { Richa } \\
\text { rds }\end{array}$ & $\begin{array}{l}\text { HT_co } \\
\text { nd }\end{array}$ & No & Yes & $\begin{array}{l}\text { Vapor; } \\
\text { HT_convect } \\
\text { (liquid) }\end{array}$ & $\begin{array}{l}\text { Multila } \\
\text { yer }\end{array}$ & $\begin{array}{l}\text { HT_co } \\
\text { nd }\end{array}$ & $\begin{array}{l}\text { Mass } \\
\text { conserva } \\
\text { tion, } \\
\text { vapor }\end{array}$ & $\begin{array}{l}\text { Albedo_SN } \\
\text { W_3D }\end{array}$ & $\begin{array}{l}\text { Density_SN } \\
\text { W_4G }\end{array}$ & $\begin{array}{l}\text { Explicit prognostic } \\
\text { settlement; } \\
\text { Snow metamorphism; } \\
\text { compaction; wind drift; } \\
\text { sublimation }\end{array}$ & $\begin{array}{l}\text { Lehning et al. } \\
\text { (1999) }\end{array}$ \\
\hline WEB-DHM & $\begin{array}{l}\text { Richa } \\
\text { rds }\end{array}$ & $\begin{array}{l}\text { HT_co } \\
\text { nd }\end{array}$ & No & No & $\begin{array}{l}\text { No vapor; } \\
\text { LH_phas }\end{array}$ & Single & $\begin{array}{l}\text { HT_co } \\
\text { nd }\end{array}$ & $\begin{array}{l}\text { Mass } \\
\text { conserva } \\
\text { tion }\end{array}$ & $\begin{array}{l}\text { Albedo_SN } \\
\text { W_1B }\end{array}$ & Constant & Vegetation interception & $\begin{array}{l}\text { Wang et al. } \\
\text { (2009) }\end{array}$ \\
\hline $\begin{array}{l}\text { WEB-DHM- } \\
\mathrm{S}\end{array}$ & $\begin{array}{l}\text { Richa } \\
\text { rds }\end{array}$ & $\begin{array}{l}\text { HT_co } \\
\text { nd }\end{array}$ & No & No & $\begin{array}{l}\text { No vapor; } \\
\text { LH_phas }\end{array}$ & $\begin{array}{l}\text { Multila } \\
\text { yer up } \\
\text { to } 3\end{array}$ & $\begin{array}{l}\text { HT_co } \\
\text { nd }\end{array}$ & $\begin{array}{l}\text { Mass } \\
\text { conserva } \\
\text { tion }\end{array}$ & $\begin{array}{l}\text { Albedo_SN } \\
\text { W_3F }\end{array}$ & $\begin{array}{l}\text { Density_SN } \\
\text { W_4B }\end{array}$ & Snow compaction & $\begin{array}{l}\text { Shrestha et al. } \\
\text { (2010) }\end{array}$ \\
\hline $\begin{array}{l}\text { HydroSiB2- } \\
\text { SF }\end{array}$ & $\begin{array}{l}\text { Richa } \\
\text { rds }\end{array}$ & $\begin{array}{l}\text { HT_co } \\
\text { nd }\end{array}$ & No & Yes & $\begin{array}{l}\text { Vapor; } \\
\text { enthalpy- } \\
\text { based FT; } \\
\text { LH_phas }\end{array}$ & $\begin{array}{l}\text { Multila } \\
\text { yer up } \\
\text { to } 3\end{array}$ & $\begin{array}{l}\text { HT_co } \\
\text { nd, } \\
\text { Advc }\end{array}$ & $\begin{array}{l}\text { Mass } \\
\text { conserva } \\
\text { tion }\end{array}$ & $\begin{array}{l}\text { Albedo_SN } \\
\text { W_3F }\end{array}$ & $\begin{array}{l}\text { Density_SN } \\
\text { W_4B }\end{array}$ & Snow compaction & $\begin{array}{l}\text { Wang et al. } \\
\text { (2017) }\end{array}$ \\
\hline WEB-GM & - & - & - & - & - & $\begin{array}{l}\text { Multila } \\
\text { yer, } \\
\text { vary } \\
\text { with } \\
\text { snow } \\
\text { depth }\end{array}$ & $\begin{array}{l}\text { Enthalp } \\
\text { y based } \\
\text { heat } \\
\text { transfer }\end{array}$ & $\begin{array}{l}\text { Mass } \\
\text { conserva } \\
\text { tion }\end{array}$ & $\begin{array}{l}\text { Albedo_SN } \\
\text { W_4 }\end{array}$ & $\begin{array}{l}\text { Density_SN } \\
\text { W_3 }\end{array}$ & $\begin{array}{l}\text { Snow compaction } \\
\text { (metamorphism, snow } \\
\text { densification, melting); }\end{array}$ & $\begin{array}{l}\text { Ding et al. } \\
\text { (2017) }\end{array}$ \\
\hline
\end{tabular}




\begin{tabular}{|c|c|c|c|c|c|c|c|c|c|c|c|c|}
\hline SWAP & $\begin{array}{l}\text { Richa } \\
\text { rds }\end{array}$ & $\begin{array}{l}\text { HT_co } \\
\text { nd }\end{array}$ & No & No & $\begin{array}{l}\text { No vapor; } \\
\text { LH_phas }\end{array}$ & Single & - & $\begin{array}{l}\text { Mass } \\
\text { conserva } \\
\text { tion }\end{array}$ & Constant & $\begin{array}{l}\text { Density_SN } \\
\text { W_4H }\end{array}$ & Vegetation interception & $\begin{array}{l}\text { Gusev and } \\
\text { Nasonova } \\
\text { (2003) }\end{array}$ \\
\hline COUP & $\begin{array}{l}\text { Richa } \\
\text { rds }\end{array}$ & $\begin{array}{l}\text { HT_co } \\
\text { nd, } \\
\text { Advc }\end{array}$ & No & Yes & $\begin{array}{l}\text { Vapor; } \\
\text { HT_convect } \\
\text { (liquid) }\end{array}$ & Single & $\begin{array}{l}\text { HT_co } \\
\text { nd }\end{array}$ & $\begin{array}{l}\text { Mass } \\
\text { conserva } \\
\text { tion }\end{array}$ & $\begin{array}{l}\text { Albedo_SN } \\
\text { W_1A }\end{array}$ & $\begin{array}{l}\text { Density_SN } \\
\text { W_2C }\end{array}$ & Snow compaction & Jansson (2012) \\
\hline SHAW & $\begin{array}{l}\text { Richa } \\
\text { rds }\end{array}$ & $\begin{array}{l}\text { HT_co } \\
\text { nd, } \\
\text { Advc }\end{array}$ & No & Yes & $\begin{array}{l}\text { Vapor; } \\
\text { HT_convect } \\
\text { (liquid, } \\
\text { vapor) }\end{array}$ & $\begin{array}{l}\text { Multila } \\
\text { yer }\end{array}$ & $\begin{array}{l}\text { HT_co } \\
\text { nd, } \\
\text { Advc }\end{array}$ & $\begin{array}{l}\text { Mass } \\
\text { conserva } \\
\text { tion, } \\
\text { vapor }\end{array}$ & $\begin{array}{l}\text { Albedo_SN } \\
\text { W_1C }\end{array}$ & $\begin{array}{l}\text { Density_SN } \\
\text { W_4E }\end{array}$ & Snow compaction, settling & $\begin{array}{l}\text { Flerchinger and } \\
\text { Saxton (1989); } \\
\text { Flerchinger } \\
\text { (2017) }\end{array}$ \\
\hline HYDRUS & $\begin{array}{l}\text { Richa } \\
\text { rds }\end{array}$ & $\begin{array}{l}\text { HT_co } \\
\text { nd, } \\
\text { Advc }\end{array}$ & No & Yes & $\begin{array}{l}\text { Vapor; } \\
\text { HT_convect } \\
\text { (liquid, } \\
\text { vapor) }\end{array}$ & - & - & - & - & - & - & $\begin{array}{l}\text { Hansson et al. } \\
\text { (2004); } \\
\text { Šimůnek et al. } \\
\text { (2008) }\end{array}$ \\
\hline $\begin{array}{l}\text { STEMMUS- } \\
\text { UEB }\end{array}$ & $\begin{array}{l}\text { Richa } \\
\text { rds }\end{array}$ & $\begin{array}{l}\text { HT_co } \\
\text { nd, } \\
\text { Advc }\end{array}$ & Yes & Yes & $\begin{array}{l}\text { Vapor; } \\
\text { LH_phas; } \\
\text { HT_convect } \\
\text { (liquid, } \\
\text { vapor, dry } \\
\text { air); Various } \\
\text { complexity of } \\
\text { SHP }\end{array}$ & Single & $\begin{array}{l}\text { HT_co } \\
\text { nd, } \\
\text { Advc }\end{array}$ & $\begin{array}{l}\text { Mass } \\
\text { conserva } \\
\text { tion }\end{array}$ & $\begin{array}{l}\text { Albedo_SN } \\
\text { W_3F }\end{array}$ & Constant & $\begin{array}{l}\text { Empirical wind drift and } \\
\text { vegetation interception }\end{array}$ & This study \\
\hline
\end{tabular}

Note:

HT_cond, Heat conduction;

Advc, Advection;

780 LH_phas, Latent heat due to phase change;

HT_Convect, Convective heat due to liquid;

SHP, soil physical process;

Albedo_SNW_1A, Snow albedo 1A, Function of snow age;

Albedo_SNW_1B, Snow albedo 1B, Empirical function, considering dry/wet states;

785 Albedo_SNW_1C, Snow albedo 1C, Function of extinction coefficient, grain-size, and solar zenith angle;

Albedo_SNW_2, Snow albedo 2, Two-stream radiative transfer solution, considering snow aging, solar zenith angle, optical parameters, and impurity;

Albedo_SNW_3A, Snow albedo 3A, Prognostic snow albedo, considering aging effect;

Albedo_SNW_3B, Snow albedo 3B, Prognostic snow albedo, considering aging effect and vegetation type dependent;

790 Albedo_SNW_3C, Snow albedo 3C, Prognostic snow albedo, considering aging and optical diameter;

Albedo_SNW_3D, Snow albedo 3D, Prognostic snow albedo, considering age and microstructure;

Albedo_SNW_3E, Snow albedo 3E, Prognostic snow albedo, considering aging effect and dry/wet states;

Albedo_SNW_3F, Snow albedo 3F, Prognostic snow albedo considering aging effect, solar zenith angle;

Albedo_SNW_4, Snow albedo 4, Diagnostic snow albedo, considering snow aging, sleet/snowfall fraction, grain diameter, cloud fraction, 795 and solar elevation effect;

Density_SNW_1, Snow density 1, relying on in situ measurements;

Density_SNW_2A, Snow density 2A, function of air temperature;

Density_SNW_2B, Snow density 2B, Function of extinction coefficient and grain-size;

Density_SNW_2C, Snow density 2C, Function of old (densification), new-fallen (air temperature) snow pack density, and snow depth;

800 Density_SNW_3, Snow density 3, Diagnostic density, considering wet-bulb temperature;

Density_SNW_4A, Snow density 4A, Prognostic density, considering temperature, wind effect, snow compaction, water/ice states;

Density_SNW_4B, Snow density 4B, Prognostic density, considering overburden and thermal metamorphisms;

Density_SNW_4C, Snow density 4C, Prognostic snow density, considering snow compaction and settling;

Density_SNW_4D, Snow density 4D, Prognostic snow density, considering snow compaction and wind-induced densification;

805 Density_SNW_4E, Snow density 4E, Prognostic snow density, considering snow compaction, settling, and vapor transfer;

Density_SNW_4F, Snow density 4F, Prognostic density, function of wind speed and air temperature;

Density_SNW_4G, Snow density 4G, Prognostic density, function of stress state and microstructure;

Density_SNW_4H, Snow density 4H, Prognostic density, considering snow temperature. 
Table 2. Main subroutines in STEMMUS-UEB

\begin{tabular}{|c|c|c|c|c|}
\hline $\begin{array}{l}\text { Model } \\
\text { Subroutines }\end{array}$ & Main functions & Main inputs & Main outputs & Subroutine-Connections \\
\hline \multicolumn{5}{|l|}{ Soil module } \\
\hline Air_sub & $\begin{array}{l}\text { Solves soil dry air balance } \\
\text { equation }\end{array}$ & $\begin{array}{l}\text { Water vapor density, diffusivity, dispersion } \\
\text { coefficient; dry air density, gas conductivity, flux; } \\
\text { liquid water flux; top and bottom boundary conditions }\end{array}$ & Soil air pressure profile & $\begin{array}{l}\text { CondV_DVg, CondL_h, } \\
\text { Condg_k_g, Density_V, } \\
\text { h_sub--->; } \\
\text {--> Enrgy_sub, }\end{array}$ \\
\hline CondL_h & $\begin{array}{l}\text { Calculates soil hydraulic } \\
\text { conductivity }\end{array}$ & $\begin{array}{l}\text { Soil hydraulic parameters; soil matric potential; soil } \\
\text { temperature }\end{array}$ & $\begin{array}{l}\text { Soil hydraulic conductivity; soil } \\
\text { water content }\end{array}$ & $\begin{array}{l}\text { StartInit --->; } \\
\text {--> h_sub; Air_sub; } \\
\text { Enrgy_sub, }\end{array}$ \\
\hline CondT_coeff & $\begin{array}{l}\text { Calculates soil thermal } \\
\text { capacity and conductivity }\end{array}$ & $\begin{array}{l}\text { Thermal properties of soil constituents; soil texture; } \\
\text { soil water content; volumetric fraction of dry air; dry } \\
\text { air density; vapor density }\end{array}$ & $\begin{array}{l}\text { Soil thermal capacity and } \\
\text { conductivity }\end{array}$ & $\begin{array}{l}\text { StartInit, CondL_h, Density_V, } \\
\text { Density_DA, EfeCapCond -- } \\
\text {->; } \\
\text {--> Enrgy_sub, }\end{array}$ \\
\hline CondV_DVg & $\begin{array}{l}\text { Calculates flux of dry air and } \\
\text { vapor dispersity }\end{array}$ & $\begin{array}{l}\text { Gas conductivity, dry air pressure, volumetric fraction } \\
\text { of dry air; saturated soil water content }\end{array}$ & $\begin{array}{l}\text { Dry air flux and vapor } \\
\text { dispersion coefficient }\end{array}$ & $\begin{array}{l}\text { Startlnit, CondL_h, } \\
\text { Condg_k_g --->; } \\
\text {--> h_sub; Air_sub; } \\
\text { Enrgy_sub, }\end{array}$ \\
\hline CondL_Tdisp & $\begin{array}{l}\text { Calculates transport } \\
\text { coefficient for adsorbed } \\
\text { liquid flow }\end{array}$ & $\begin{array}{l}\text { Soil porosity, soil water content, temperature, matric } \\
\text { potential, volumetric fraction of dry air }\end{array}$ & $\begin{array}{l}\text { Transport coefficient for } \\
\text { adsorbed liquid flow and the } \\
\text { heat of wetting }\end{array}$ & $\begin{array}{l}\text { StartInit, CondL_h, } \\
\text { Condg_k_g --->; } \\
-->\text { h_sub; Enrgy_sub, }\end{array}$ \\
\hline Condg_k_g & Calculates gas conductivity & $\begin{array}{l}\text { Soil porosity, saturated hydraulic conductivity, } \\
\text { volumetric fraction of dry air }\end{array}$ & Gas conductivity & $\begin{array}{l}\text { StartInit, CondL_h --->; } \\
-->\text { CondV_DVg, }\end{array}$ \\
\hline Density_DA & Calculates dry air density & $\begin{array}{l}\text { Soil temperature, matric potential, dry air pressure; } \\
\text { vapor density and its derivative with respect to } \\
\text { temperature and matric potential }\end{array}$ & Density of dry air & $\begin{array}{l}\text { StartInit, CondL_h, Density_V } \\
--->; \\
-->\text { CondT_coeff, Air_sub, } \\
\text { Enrgy_sub, }\end{array}$ \\
\hline Density_V & $\begin{array}{l}\text { Calculates vapor density and } \\
\text { its derivative with respect to } \\
\text { temperature and matric } \\
\text { potential }\end{array}$ & Soil temperature, matric potential & $\begin{array}{l}\text { Vapor density and its derivative } \\
\text { with respect to temperature and } \\
\text { matric potential }\end{array}$ & $\begin{array}{l}\text { CondL_h --->; } \\
\text {--> Density_DA, CondT_coeff, } \\
\text { h_sub, Air_sub, Enrgy_sub, }\end{array}$ \\
\hline EfeCapCond & $\begin{array}{l}\text { Calculates soil thermal } \\
\text { capacity and conductivity }\end{array}$ & $\begin{array}{l}\text { Thermal properties of soil constituents; soil texture; } \\
\text { soil water content; volumetric fraction of dry air; dry } \\
\text { air density; vapor density }\end{array}$ & $\begin{array}{l}\text { Soil heat capacity; thermal } \\
\text { conductivity }\end{array}$ & $\begin{array}{l}\text { Startlnit, CondL_h, Density_V, } \\
\text { Density_DA --->; } \\
\text {--> CondT_coeff, }\end{array}$ \\
\hline Enrgy_sub & $\begin{array}{l}\text { Solves soil energy balance } \\
\text { equation }\end{array}$ & $\begin{array}{l}\text { Soil thermal properties, soil hydraulic conductivity, } \\
\text { soil matric potential, soil water content, soil } \\
\text { temperature, soil dry air pressure, density of dry air, } \\
\text { heat of wetting, vapor density, liquid water flux, vapor } \\
\text { flux, dry air flux, meterological forcing, top and } \\
\text { bottom boundary conditions }\end{array}$ & $\begin{array}{l}\text { Soil temperature profile, liquid } \\
\text { water flux, vapor flux, and dry } \\
\text { air flux, surface and bottom } \\
\text { energy fluxes }\end{array}$ & $\begin{array}{l}\text { Air_sub, h_sub, CondL_h, } \\
\text { CondV_DVg, CondL_Tdisp, } \\
\text { CondT_coeff, Density_D, } \\
\text { Density_DA, PREDICORR -- } \\
\text {->, }\end{array}$ \\
\hline $\begin{array}{l}\text { Forcing_PAR } \\
\text { M }\end{array}$ & $\begin{array}{l}\text { Disaggregates the } \\
\text { meteorological forcing into } \\
\text { the required time steps }\end{array}$ & $\begin{array}{l}\text { Observed meteorological forcing at hourly/daily time } \\
\text { scale }\end{array}$ & $\begin{array}{l}\text { Meteorological forcings at } \\
\text { model required time scale }\end{array}$ & $\begin{array}{l}\text { Startlnit --->; } \\
-->\text { h_sub, Enrgy_sub, }\end{array}$ \\
\hline h_sub & $\begin{array}{l}\text { Solves soil water balance } \\
\text { equation }\end{array}$ & $\begin{array}{l}\text { Soil temperature, soil water content, matric potential, } \\
\text { soil hydraulic conductivity, heat of wetting, soil dry } \\
\text { air pressure, vapor density, diffusivity, dispersity, } \\
\text { volumetric fraction of vapor, meteorological forcing, } \\
\text { top and bottom boundary conditions }\end{array}$ & $\begin{array}{l}\text { Soil matric potential profile, top } \\
\text { and bottom water fluxes, } \\
\text { evaporation }\end{array}$ & $\begin{array}{l}\text { StartInit, CondV_DVg, } \\
\text { CondL_h, CondV_DE, } \\
\text { CondL_Tdisp, Condg_k_g, } \\
\text { Density_V, Forcing_PARM, } \\
\text { ALBEDO, PARTSNOW, } \\
\text { PREDICORR --->; }\end{array}$ \\
\hline Startlnit & Initializes model setup & $\begin{array}{l}\text { Soil texture, thermal properties of soil constituents, } \\
\text { initial soil water content and temperature, top and } \\
\text { bottom boundary condition settings }\end{array}$ & - & $\begin{array}{l}\text {--> Air_sub, Enrgy_sub, } \\
\text {--> CondV_DVg, CondL_h, } \\
\text { CondV_DE, CondL_Tdisp, } \\
\text { Condg_k_g, Density_DA, } \\
\text { EfeCapCond, Forcing_PARM, } \\
\text { h_sub, }\end{array}$ \\
\hline $\begin{array}{l}\text { Diff_Moisture_ } \\
\text { Heat }\end{array}$ & $\begin{array}{l}\text { Solves soil water and energy } \\
\text { balance equations } \\
\text { independently }\end{array}$ & $\begin{array}{l}\text { Soil thermal properties, soil hydraulic conductivity, } \\
\text { soil matric potential, soil water content, soil } \\
\text { temperature, meteorological forcing, top and bottom } \\
\text { boundary conditions }\end{array}$ & $\begin{array}{l}\text { Soil water content and } \\
\text { temperature profile, liquid } \\
\text { water flux, surface and bottom } \\
\text { water and energy fluxes }\end{array}$ & $\begin{array}{l}\text { Startlnit, CondT_coeff, } \\
\text { Forcing_PARM, ALBEDO, } \\
\text { PARTSNOW, PREDICORR -- } \\
->\text {, }\end{array}$ \\
\hline \multicolumn{5}{|l|}{$\begin{array}{l}\text { Snowpack } \\
\text { module }\end{array}$} \\
\hline agesn & Calculates snow age & Snow surface temperature, snowfall & Updated snow age & $\begin{array}{l}\text { PARTSNOW, PREDICORR -- } \\
->; \\
-->\text { ALBEDO, }\end{array}$ \\
\hline ALBEDO & Calculates snow albedo & $\begin{array}{l}\text { Fresh snow reflectance at visible and near infrared } \\
\text { bands, snow age, bare ground albedo, albedo } \\
\text { extinction parameter, snow water equivalent }\end{array}$ & Snow albedo & $\begin{array}{l}\text { agesn --->; } \\
\text {--> PREDICORR, }\end{array}$ \\
\hline PARTSNOW & $\begin{array}{l}\text { Partitions precipitation into } \\
\text { rainfall and snowfall }\end{array}$ & $\begin{array}{l}\text { Precipitation, air temperature, temperature thresholds } \\
\text { for rainfall/snowfall }\end{array}$ & Rainfall, snowfall & $\begin{array}{l}\text { Forcing_PARM --->; } \\
\text {--> PREDICORR, }\end{array}$ \\
\hline
\end{tabular}


https://doi.org/10.5194/gmd-2020-416

Preprint. Discussion started: 17 February 2021

(C) Author(s) 2021. CC BY 4.0 License.

Solves the snow mass and

energy balance equations and Air temperature, snow albedo, wind speed, relative ence and $\mathrm{U}$
Snow energy content, water

equivalent, snow albedo, snow Forcing PARM --->;

surface temperature, meltwater Forcing_PARM --->;

outflow rate, snow sublimation, snowfall/rainfall

810

\section{Note:}

---> means the relevant subroutines which are incoming to the current one, --> means the relevant subroutines for which the current subroutine is output to;

agesn $^{2}$ and $\mathrm{ALBEDO}^{2}$, means the use of subroutines agesn and ALBEDO after solving the snowpack energy and mass conservation equations, to update the snow age and albedo. 
https://doi.org/10.5194/gmd-2020-416

Preprint. Discussion started: 17 February 2021

(C) Author(s) 2021. CC BY 4.0 License.

Table 3. Numerical experiments with various mass and energy transfer schemes with/without explicit consideration of snow cover (Eqs. A1-A7 are listed in Appendix A.1; Eqs. A8-A9 are listed in Appendix A.2).

\begin{tabular}{|c|c|c|c|}
\hline \multicolumn{2}{|l|}{ Processes } & \multirow{2}{*}{ Experiments } & \\
\hline Snowpack (SNW) & Mass and energy transfer in soils (SMETr) & & \\
\hline \multirow{3}{*}{$\begin{array}{l}\text { SNW }=1: \\
\text { UEB (Eqs. A.8 \& A.9) }\end{array}$} & SMETr=1: basic coupled water-heat transfer (Eqs. A.1 \& A.2) & BCD-Snow & \multirow{3}{*}{ STEMMUS-FT_Snow } \\
\hline & $\begin{array}{l}\text { SMETr=2: advanced coupled water-heat transfer without air flow (Eqs. A.3 \& } \\
\text { A.4) }\end{array}$ & ACD-Snow & \\
\hline & $\begin{array}{l}\text { SMETr=3: advanced coupled water-heat transfer with air flow (Eqs. A.5, A.6 \& } \\
\text { A.7) }\end{array}$ & ACD-air-Snow & \\
\hline \multirow{3}{*}{$\begin{array}{l}\text { SNW }=0 \text { : } \\
\text { No discrimination of snow } \\
\text { and rainfall }\end{array}$} & SMETr=1: basic coupled water-heat transfer (Eqs. A.1 \& A.2) & BCD-No-Snow & \multirow{3}{*}{ STEMMUS-FT_No-snow } \\
\hline & $\begin{array}{l}\text { SMETr=2: advanced coupled water-heat transfer without air flow (Eqs. A.3 \& } \\
\text { A.4) }\end{array}$ & ACD-No-Snow & \\
\hline & $\begin{array}{l}\text { SMETr=3: advanced coupled water-heat transfer with air flow (Eqs. A.5, A.6 \& } \\
\text { A.7) }\end{array}$ & ACD-air-No-Snow & \\
\hline
\end{tabular}


Table 4. Comparative statistics values of various model versions for snow albedo, LE, soil temperature, and soil moisture. The best statistical performance is highlighted by bold fonts, while the values with poor statistical model performance is underlined with the italic fonts.

\begin{tabular}{|c|c|c|c|c|c|c|c|c|c|c|c|c|c|c|}
\hline \multirow{2}{*}{ Experiments } & & \multirow{2}{*}{ Statistics } & \multirow{2}{*}{ Snow albedo } & \multirow{2}{*}{$\mathrm{LE}(\mathrm{mm} / \mathrm{d})$} & \multicolumn{5}{|c|}{ Soil temperature $\left({ }^{\circ} \mathrm{C}\right)$} & \multicolumn{5}{|c|}{ Soil moisture $\left(\mathrm{cm}^{3} \mathrm{~cm}^{-3}\right)$} \\
\hline & & & & & $5 \mathrm{~cm}$ & $10 \mathrm{~cm}$ & $20 \mathrm{~cm}$ & $40 \mathrm{~cm}$ & $80 \mathrm{~cm}$ & $5 \mathrm{~cm}$ & $10 \mathrm{~cm}$ & $20 \mathrm{~cm}$ & $40 \mathrm{~cm}$ & $80 \mathrm{~cm}$ \\
\hline \multirow{9}{*}{$\begin{array}{l}\text { STEMMUS- } \\
\text { FT_Snow }\end{array}$} & \multirow{3}{*}{ BCD } & BIAS & -0.0100 & $\underline{0.162}$ & -0.071 & $\underline{0.150}$ & -0.048 & -1.127 & -0.1390 & 0.0064 & 0.0091 & 0.0048 & 0.0031 & $1.80 \mathrm{E}-03$ \\
\hline & & $\mathrm{R}^{2}$ & 0.296 & 0.278 & 0.976 & 0.958 & 0.881 & 0.626 & 0.810 & 0.704 & $\underline{0.586}$ & $\underline{0.310}$ & $\underline{0.387}$ & $\underline{0.237}$ \\
\hline & & RMSE & 0.033 & 0.579 & 0.4697 & 0.415 & 0.544 & 1.548 & 0.5352 & 0.0194 & 0.0223 & 0.0307 & 0.0322 & 0.0118 \\
\hline & \multirow{3}{*}{ ACD } & BIAS & -0.0049 & -0.020 & -0.224 & 0.054 & -0.032 & -0.982 & 0.0129 & -0.0014 & 0.0024 & 0.0001 & 0.0045 & 7.57E-04 \\
\hline & & $\mathrm{R}^{2}$ & 0.253 & 0.232 & 0.964 & 0.969 & 0.971 & 0.944 & 0.995 & 0.878 & 0.960 & 0.991 & 0.992 & 0.982 \\
\hline & & RMSE & 0.032 & 0.305 & 0.4462 & 0.374 & 0.209 & 1.190 & 0.1201 & 0.0087 & 0.0041 & 0.0028 & 0.0055 & 0.0019 \\
\hline & \multirow{3}{*}{ ACD-air } & BIAS & -0.0048 & -0.019 & -0.223 & 0.055 & -0.032 & -0.982 & 0.0130 & -0.0013 & 0.0025 & 0.0001 & 0.0045 & 7.55E-04 \\
\hline & & $\mathrm{R}^{2}$ & 0.338 & 0.217 & 0.963 & 0.969 & 0.971 & 0.944 & 0.995 & 0.883 & 0.960 & 0.990 & 0.992 & 0.982 \\
\hline & & RMSE & 0.031 & 0.314 & 0.4464 & 0.374 & 0.210 & 1.190 & 0.1200 & 0.0084 & 0.0042 & 0.0028 & 0.0055 & 0.0019 \\
\hline \multirow{9}{*}{$\begin{array}{l}\text { STEMMUS- } \\
\text { FT_No-snow }\end{array}$} & \multirow{3}{*}{ BCD } & BIAS & -0.0123 & $\underline{0.157}$ & -0.073 & $\underline{0.149}$ & -0.048 & -1.128 & -0.1397 & 0.0099 & 0.0092 & 0.0048 & 0.0031 & $1.70 \mathrm{E}-03$ \\
\hline & & $\mathrm{R}^{2}$ & - & 0.303 & 0.976 & 0.958 & 0.881 & 0.627 & 0.810 & 0.771 & $\underline{0.581}$ & $\underline{0.309}$ & $\underline{0.386}$ & $\underline{0.240}$ \\
\hline & & RMSE & 0.038 & 0.565 & 0.4673 & 0.415 & 0.544 & 1.548 & 0.5354 & 0.0261 & 0.0224 & 0.0307 & 0.0322 & 0.0117 \\
\hline & \multirow{3}{*}{ ACD } & BIAS & -0.0079 & -0.031 & -0.213 & 0.065 & -0.023 & -0.977 & 0.0154 & -0.0010 & 0.0026 & 0.0002 & 0.0046 & 8.29E-04 \\
\hline & & $\mathrm{R}^{2}$ & - & 0.363 & 0.964 & 0.969 & 0.973 & 0.943 & 0.995 & 0.887 & 0.959 & 0.991 & 0.991 & 0.979 \\
\hline & & RMSE & 0.037 & 0.242 & 0.4352 & 0.370 & 0.201 & 1.186 & 0.1210 & 0.0081 & 0.0044 & 0.0028 & 0.0058 & 0.0020 \\
\hline & \multirow{3}{*}{ ACD-air } & BIAS & -0.0079 & -0.031 & -0.210 & 0.072 & -0.014 & -0.968 & 0.0222 & -0.0011 & 0.0026 & 0.0003 & 0.0049 & $9.13 \mathrm{E}-04$ \\
\hline & & $\mathrm{R}^{2}$ & - & 0.358 & 0.965 & 0.969 & 0.972 & 0.943 & 0.995 & 0.886 & 0.960 & 0.991 & 0.990 & 0.979 \\
\hline & & RMSE & 0.037 & 0.243 & 0.4349 & 0.374 & 0.202 & 1.180 & 0.1198 & 0.0082 & 0.0041 & 0.0028 & 0.0061 & 0.0020 \\
\hline
\end{tabular}

Note: $B I A S=\frac{\sum_{i=1}^{n}\left(y_{i}-\widehat{y}_{l}\right)}{n}, R^{2}=1-\frac{\sum_{i=1}^{n}\left(y_{i}-\widehat{y}_{l}\right)^{2}}{\sum_{i=1}^{n}\left(y_{i}-\bar{y}\right)^{2}}, R M S E=\sqrt{\frac{\sum_{i=1}^{n}\left(y_{i}-\widehat{y}_{l}\right)^{2}}{n}}$, where $y_{i}, \widehat{y}_{l}$, are the measured and model simulated values of the selected variable (snow albedo, LE, soil temperature/moisture); $\bar{y}$ is the mean values of the measurements of the selected variable (snow albedo, LE, soil temperature/moisture); $n$ is the number of data points. 


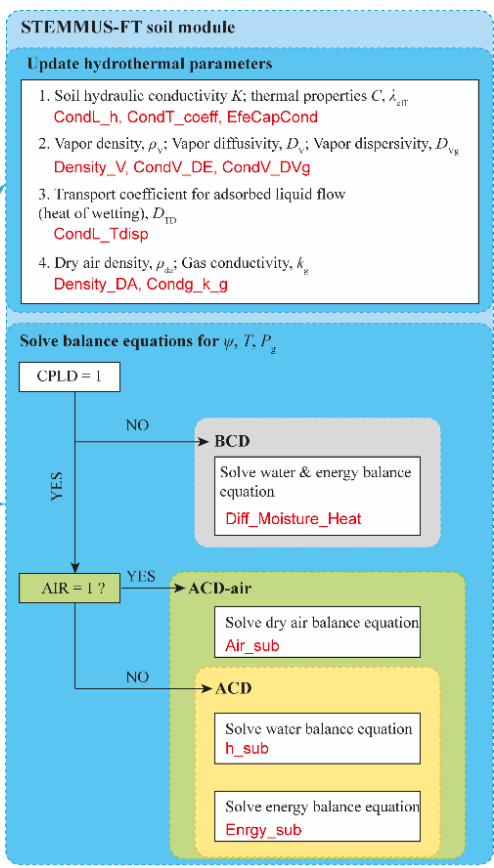

Figure 1. The overview of the coupled STEMMUS-FT and UEB model framework and model structure. SFCC is soil freezing characteristic curve; $\theta_{L}$ and $\theta_{i}$ are soil liquid water and ice content; $K_{L h}$ is soil hydraulic conductivity; $\lambda_{e f f}$ is thermal conductivity. $\psi, T, P_{g}$ are the state variables for soil module STEMMUS-FT (matric potential, temperature, and air pressure, respectively). U,

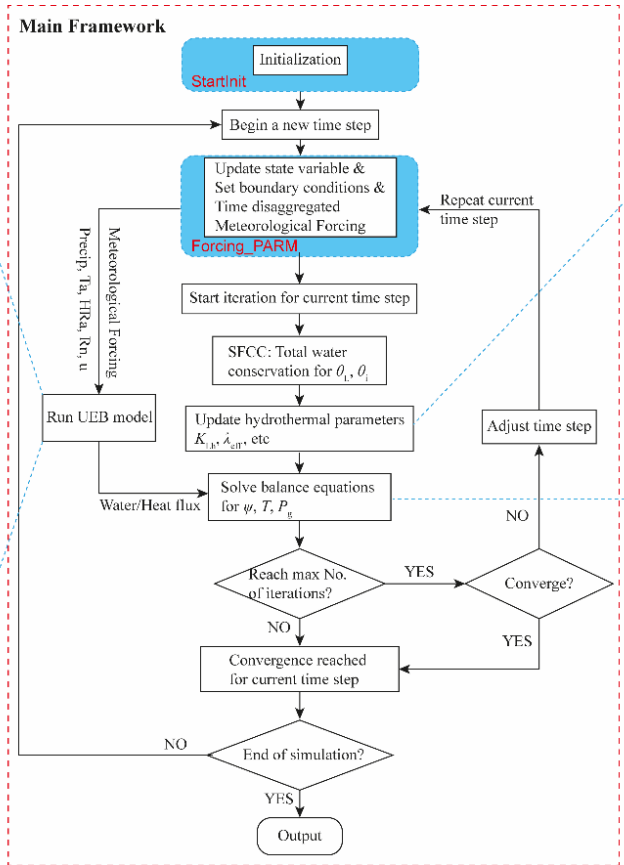
SWE, and $\tau$ are the state variables for snow module UEB (snow energy content, snow water equivalent, and snow age, respectively). UEB, Utah Energy Balance module. Precip, Ta, HRa, Rn, and u are the meteorological inputs (precipitation, air temperature, relative humidity, radiation and wind speed). Model subroutines are in red fonts. 
https://doi.org/10.5194/gmd-2020-416

Preprint. Discussion started: 17 February 2021

(C) Author(s) 2021. CC BY 4.0 License.
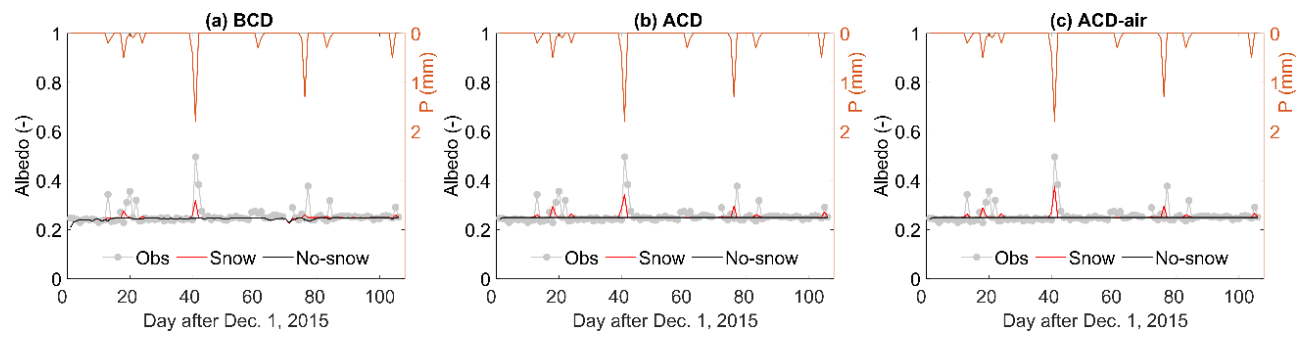

Figure 2. Time series of observed and model simulated daily average albedo using (a) BCD, (b) ACD, and (c) ACDair soil model with/without consideration of snow module with the precipitation. 




BCD


ACD
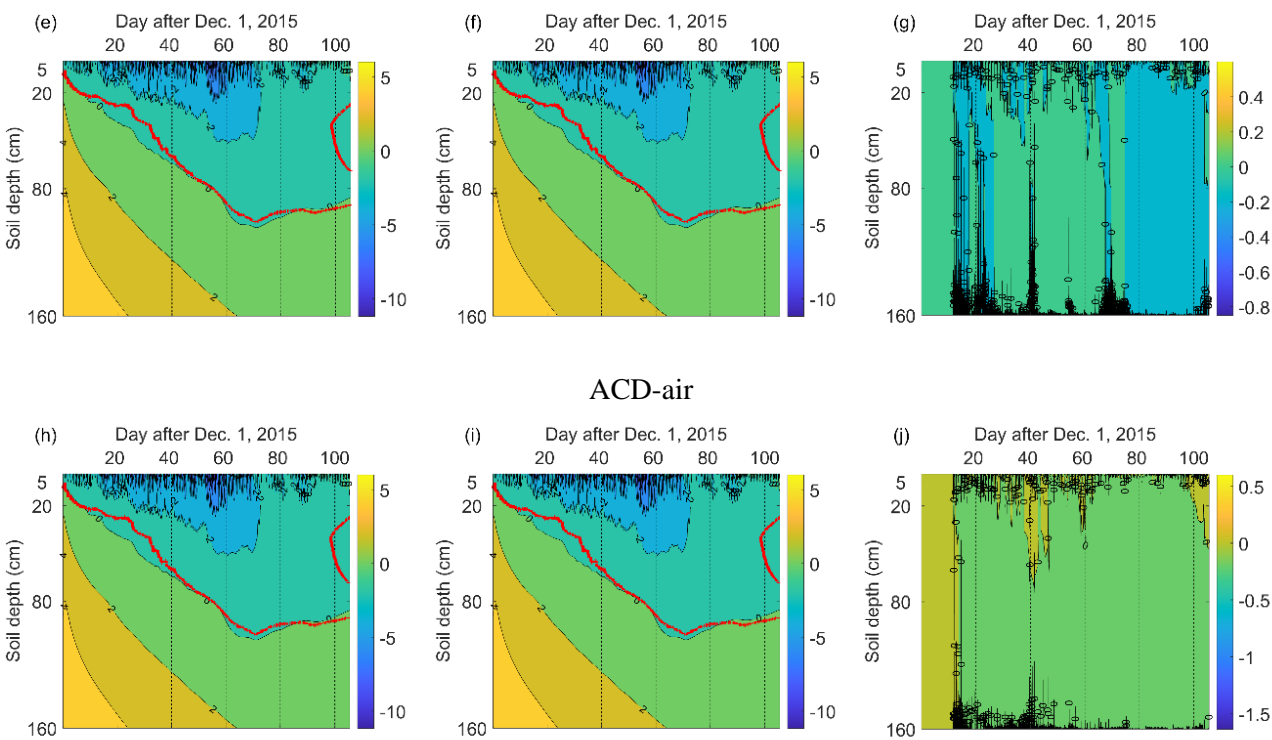

Figure 3. The spatial and temporal dynamics of observed (a) and simulated soil temperature using BCD, ACD, and ACD-air soil model, with and without consideration of snow module (Snow: b, e, h and No-Snow: $c, f, i)$ and the difference ( $d, g, j)$ (simulations with snow minus simulations without snow). The red line indicates the zero degree isothermal line (ZDIL) from the measured soil temperature. The observed soil freezing stage and 


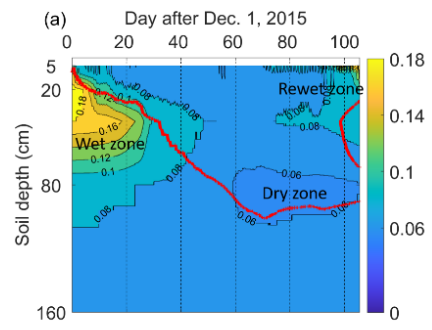

BCD


ACD
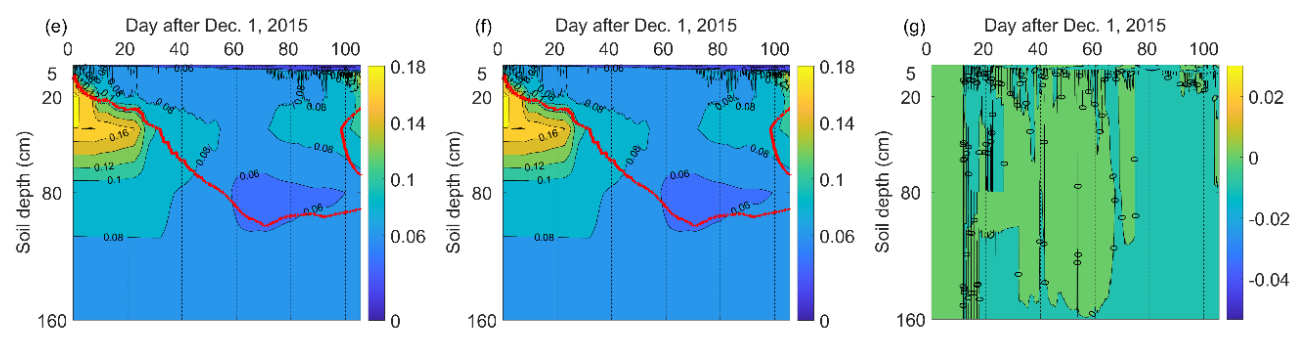

ACD-air
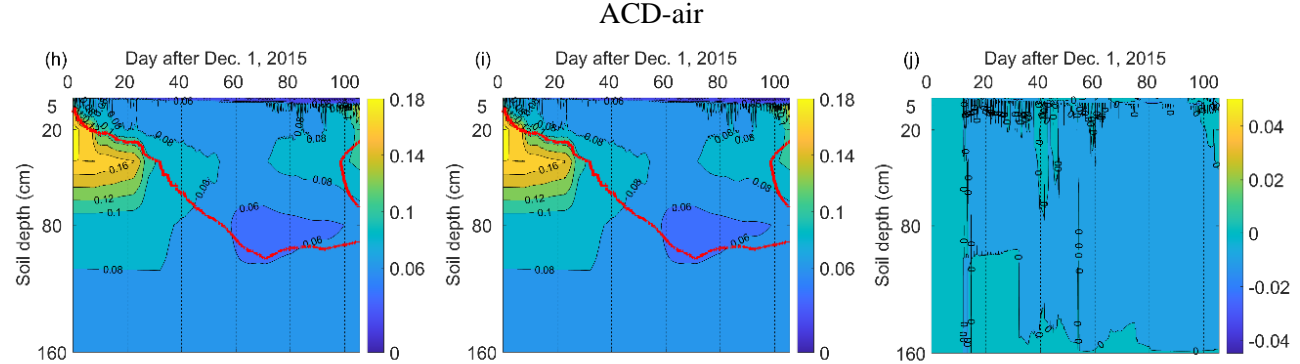

Figure 4. The spatial and temporal dynamics of observed (a) and simulated soil volumetric water content using BCD, ACD, and ACD-air soil model, with and without consideration of snow module (Snow: b, e, h and No-Snow: $c, f, i)$ and the difference $(d, g, j)$ (simulations with snow minus simulations without snow). The red line indicates the zero isotherm line from the measured soil temperature. The observed wet zone, dry zone and rewet zone of soil moisture was indicated in Fig. 4a. 
https://doi.org/10.5194/gmd-2020-416

Preprint. Discussion started: 17 February 2021

(C) Author(s) 2021. CC BY 4.0 License.


Figure 5. Time series of observed and model simulated surface cumulative latent heat flux using (a) BCD, (b) ACD, and (c) ACD-air soil model with/without consideration of snow module with the precipitation. 

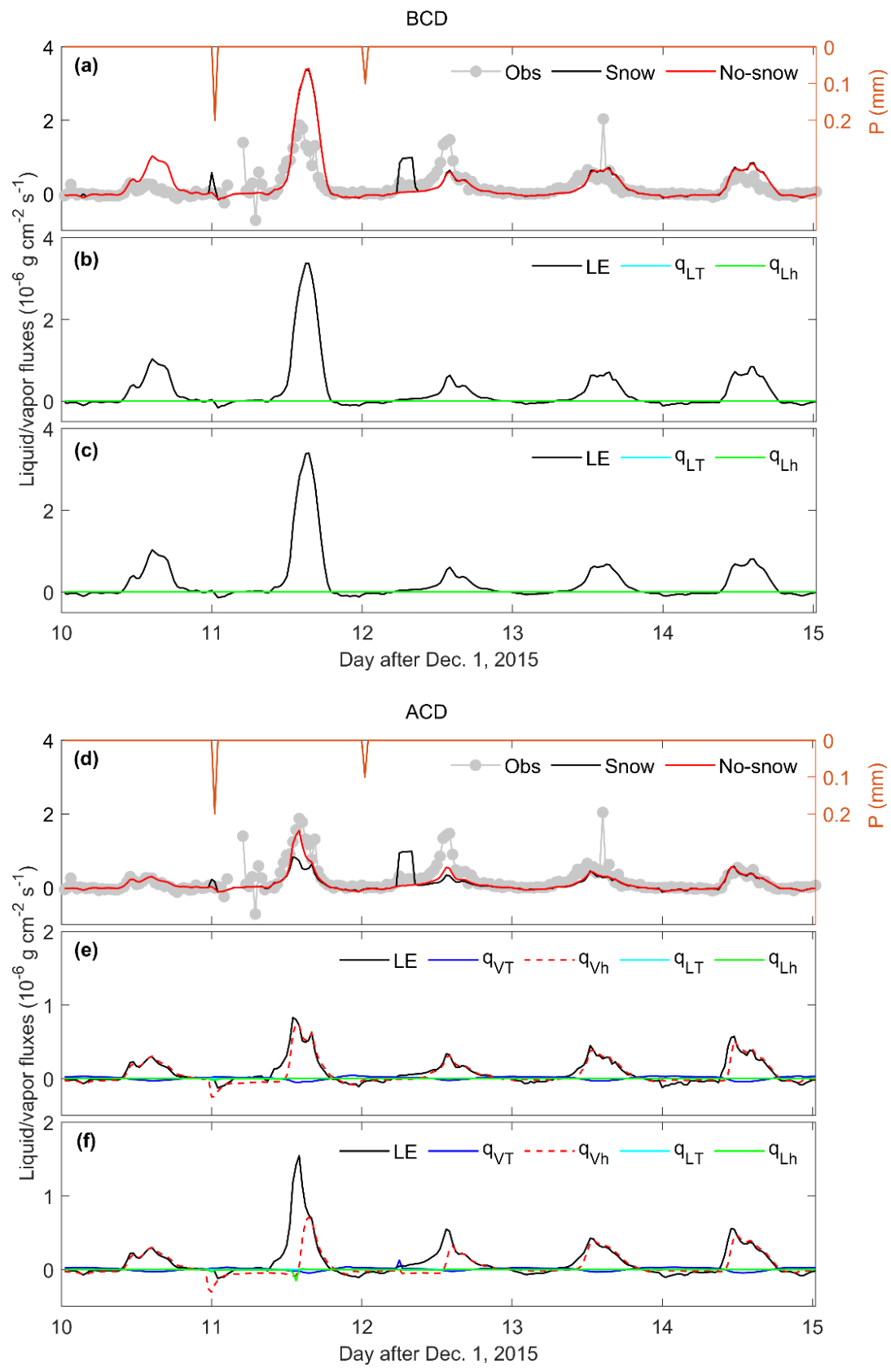




Figure 6. Observed latent heat flux and simulated latent heat flux and surface soil $(0.1 \mathrm{~cm})$ thermal and isothermal liquid water and vapor fluxes (LE, qvT, $q_{\mathrm{Vh}}, \mathrm{q}_{\mathrm{LT}}, \mathrm{q}_{\mathrm{Lh}}, \mathrm{q}_{\mathrm{La}}, \mathrm{q}_{\mathrm{Va}}$ ) with snow module and without snow module of a typical five-day freezing period (from $10^{\text {th }}$ to $14^{\text {th }}$ Days after Dec. 1. 2015). a, $\mathrm{d}$, g are the comparison results of LE 855 for BCD, ACD, and ACD-air soil model with/without snow module, respectively; b, e, $h$ are the surface soil thermal/isothermal liquid water and vapor fluxes simulated by BCD-Snow, ACD-Snow, and ACD-air-Snow model, respectively. $c, f$, $i$ are the surface soil thermal/isothermal liquid water and vapor fluxes simulated by BCDNo-Snow, ACD-No-Snow, and ACD-air-No-Snow model, respectively. LE is the latent heat flux, qvi, qvh are the water vapor fluxes driven by temperature and matric potential gradients, $q_{L T}$, $q_{L h}$ are the liquid water fluxes driven by temperature and matric potential gradients, $q_{\mathrm{La}}, \mathrm{qva}_{\mathrm{a}}$ are the liquid and vapor water fluxes driven by air pressure gradients. Positive/negative values indicate upward/downward fluxes. Note that the surface LE fluxes without snow sublimation were presented in $\mathbf{e} \& \mathbf{h}$. 

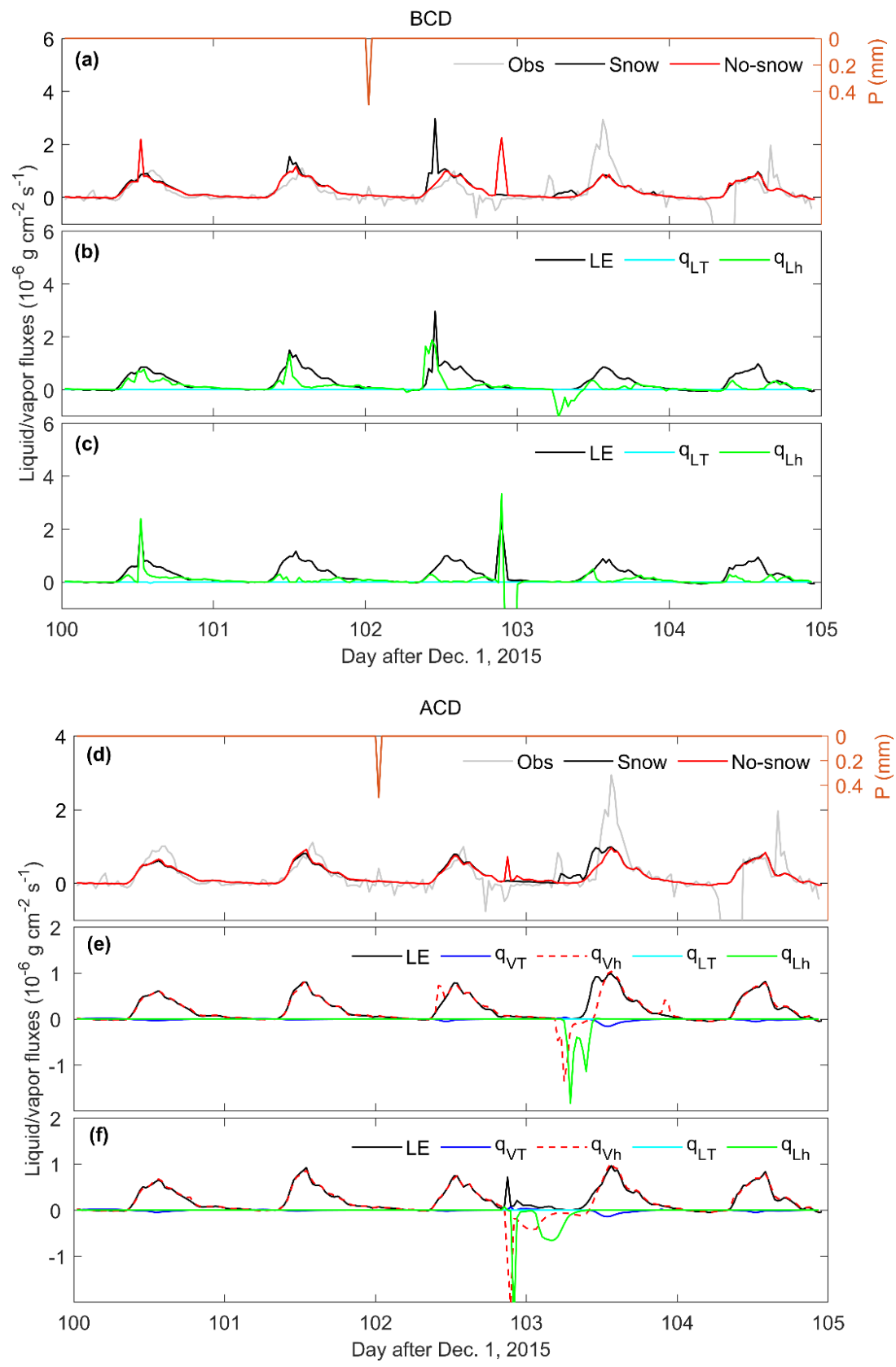


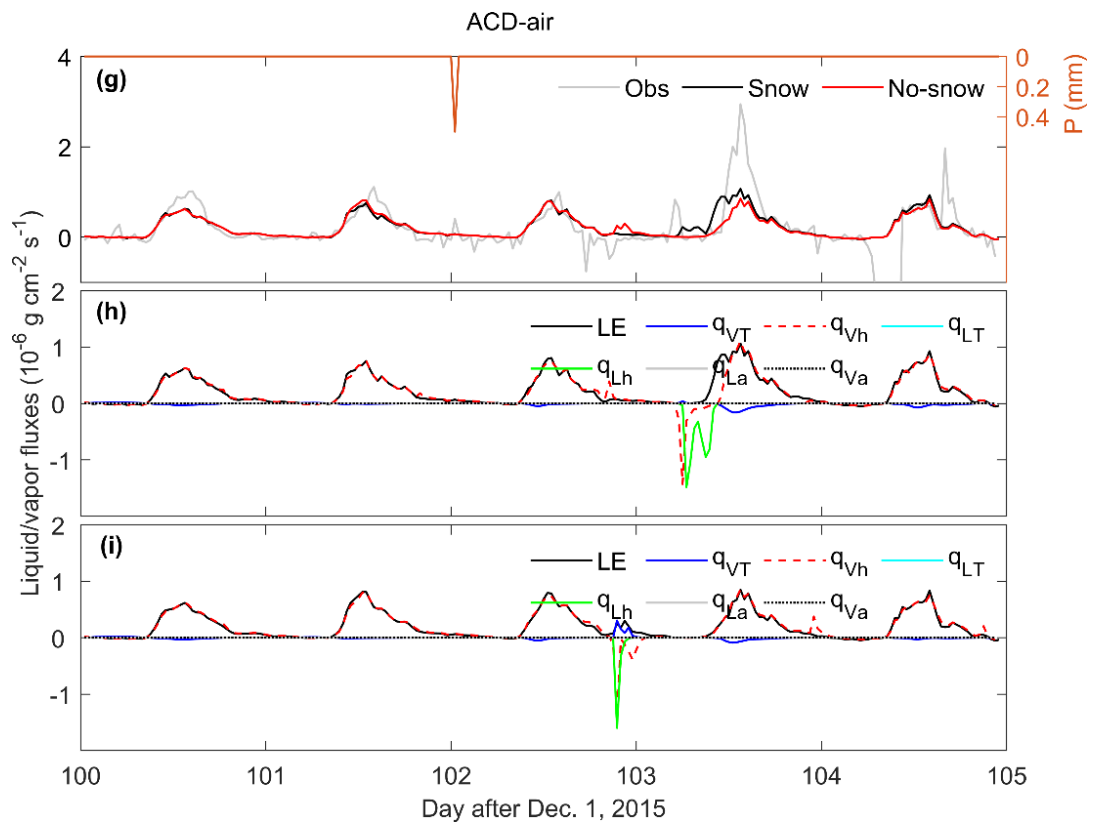

Figure 7. Observed latent heat flux and model simulated latent heat flux and surface soil $(0.1 \mathrm{~cm})$ thermal and isothermal liquid water and vapor fluxes (LE, $\left.q_{V T}, q_{V h}, q_{L T}, q_{L h}, q_{L a}, q_{V a}\right)$ using BCD (a, b, c), ACD (d, e, f), and ACD-air (g, h, i) simulations with and without snow module, respectively, during the typical 5-day thawing periods (from $100^{\text {th }}$ to $105^{\text {th }}$ Days after Dec. 1. 2015). a, d, $g$ are the comparison results of LE for BCD, ACD, and ACDair soil model with/without snow module, respectively; $b, e, h$ are the surface soil thermal/isothermal liquid water and vapor fluxes simulated by BCD-Snow, ACD-Snow, and ACD-air-Snow model, respectively. c, f, $i$ are the surface soil thermal/isothermal liquid water and vapor fluxes simulated by BCD-No-Snow, ACD-No-Snow, and ACD-air-No-Snow model, respectively. LE is the latent heat flux, $q_{v T}, q_{v h}$ are the water vapor fluxes driven by temperature and matric potential gradients, $q_{L T}, q_{L h}$ are the liquid water fluxes driven by temperature and matric potential gradients, $\mathrm{q}_{\mathrm{La}}$, $\mathrm{q}_{\mathrm{V}}$ are the liquid and vapor water fluxes driven by air pressure gradients. Positive/negative values indicate upward/downward fluxes. Note that the surface LE fluxes without snow sublimation were presented in $\mathbf{e} \& \mathbf{h}$. 